\title{
Çalışanların Sürdürülebilirlik Davranışları ve Sürdürülebilir Çalışma Yaşamı için İnsan Kaynakları Yönetimi: Türkiye'den İki Kesit
}

\author{
Çiğdem Vatansever ${ }^{1}$ (1)
}

\author{
Nevin Kılıç² (1)
}

Gülesra Dinler ${ }^{3}$ (1)

\begin{abstract}
Öz
Dünyadaki başka hiçbir gücün iş dünyasının sürdürülebilir bir dünyaya giden dönüşüm sürecinde ortaya koyacağı etkiye sahip olmadığı açıktır. Çalışanlar hem kendi şrketlerinin çevreye verdiği zarara aracı olmakta hem de bu zararlardan doğrudan etkilenebilmektedirler. Bu nedenle, organizasyonlardaki çalışanların çevreyi korumaya yönelik tutum ve davranışlarının geliştirilmesi, iş dünyasının sürdürülebilirliği için kritiktir. Çalışmamız, Türkiye'de şirketlerin sürdürülebilirlik uygulamalarına çalışanlar açııından daha yakından bakmayı hedeflemektedir. Bu amaçla iki ayrı çalışmayla, kurumlarda çalışanların çevreye yönelik tutum ve davranışları ve önde gelen şirketlerin çalışanları başta olmak üzere insan odaklı uygulamaları insan kaynakları yönetimi perspektifinden değerlendirilmiştir. Çevre dostu uygulamaların varlığı çalışanların çevre konusunda aktivist davranışlarını artırmaktadır. İkinci çalışmanın en temel bulgusu olarak, kurumların insan sürdürülebilirlik raporlarında insan kaynakları yönetimine ilişkin en çok, "yeteneği cezbetme ve çalışanların tercih ettiği bir şirket olma" ile "çalışanlar üzerindeki negatif etkilerin azaltılması" konularına yer verdikleri görülmektedir.
\end{abstract}

\section{Anahtar Sözcükler}

Sürdürülebilirlik • Sürdürülebilir insan kaynakları yönetimi • Çalışanların yeşil davranışları

Employees' Sustainability Behaviors and Human Resources Management for Sustainable Working Life: Two Sections from Turkey

\section{Abstract}

It is clear that no other power in the world has the kind of influence as the business world has to offer in the process of transforming into a sustainable world. Employees are not only agencies of their own companies on damage to environment but also they are directly affected by these damages. For this reason, it is critical for the sustainability of the business world to improve the attitudes and behaviors of employees to ensure the organization to protect the environment. This study aims to take a closer look at the sustainability practices of companies in Turkey. For this purpose, two different studies were carried out: the first one about the attitudes and behaviors of the employees and the second one for human-focused practices of the leading companies, from the perspective of human resources management. Findings show that, the presence of environmentally friendly practices increases the environmentally activist behavior of employees. The main finding of the second study is that organizations are mostly involved in "attracting talent and being a company preferred by employees" and "reducing the negative effects on employees" in relation to human resources management in sustainability reporting.

\section{Keywords}

Sustainability • Sustainable human resources management • Employees' green behaviours

1 Sorumlu Yazar: Çiğdem Vatansever (Doç. Dr.), Namık Kemal Üniversitesi, Çalışma Ekonomisi ve Endüstri iliş̧kileri, İnsan Kaynakları Yönetimi Ana Bilim Dalı, Tekirdağ, Türkiye. Eposta: cvatansever@nku.edu.tr

2 Nevin Kılıç (Dr. Öğretim Görevlisi) - Fatih Sultan Mehmet Vakıf Üniversitesi, Fen Edebiyat Fakültesi, Psikoloji Bölümü İstanbul, Türkiye. Eposta:nkilic@fsm.edu.tr

3 Gülesra Dinler (Uzman) - Namık Kemal Üniversitesi, Sosyal Bilimler Enstitüsü, Tekirdağ, Türkiye.

Eposta: gulesra.dinler@bshg.com

Atıf: Vatansever, Ç., Kılıç, N. ve Dinler, E. (2018). Çalışanların sürdürülebilirlik davranışları ve sürdürülebilir çalışma yaşamı için insan kaynakları yönetimi: Türkiye'den iki kesit. Istanbul Management Journal, 29(85), 7-39.

http://dx.doi.org/10.26650/imj.2018.29.85.0007 


\section{Extended Abstract}

\section{Research Problem}

This study aims to take a closer look at the sustainability practices of companies in Turkey. For this purpose, two different studies were carried out: the first one on the attitudes and behaviors of employees and the second one on human-focused practices of the leading companies from the perspective of human resources management.

\section{Research Questions}

The research questions were set according to this objective:

a) What are the practices for environmental protection at workplaces in Turkey? (Study I)

b) What is the relationship between environmental practices and employee behaviors in the workplace? (Study I)

c) What is being done about the sustainability of human resources in the most pioneering companies in Turkey? (Study II)

d) What is the relationship between human resources management functions and sustainability? (Study II)

\section{Literature Review}

The literature of this study focuses on environmental and sustainability issues. Multiple concepts, such as sustainability, green, pro-environmental, and ecological, are used to define the efforts and practices of institutions to protect natural and social structures. It is clear that no other power in the world has the kind of influence that the business world has to offer in the process of transforming our planet into a sustainable world. Employees are not only agents of their own companies regarding damage to the environment but also are directly affected by these damages. For this reason, it is critical for the sustainability of the business world to improve the attitudes and behaviors of employees to ensure that the organization protects the environment.

\section{Methodology}

In this article, the findings of two studies were discussed in relation to their roles regarding the sustainability of human resource management and the sustainability of the environment in Turkey. The first part of this research is a quantitative study aimed at understanding and explaining employees' environmental behaviors. For this purpose, a total of 835 people, i.e., 418 women and 417 men, working in 623 private sector and 212 public sector jobs, were asked to fill two questionnaires describing their attitudes and behaviors toward the environment. The second study is a qualitative study to review what kinds of practices have been used regarding 
sustainability in Turkey's leading companies. For this purpose, sustainability reports of Fortune 500 companies from 2016 were evaluated through a content analysis method. Consequently, 11 companies have been selected since they issued reports in three succeeding years as a condition (as an indication of the firm's determination for sustainability reporting) : Arçelik, Anadolu Efes, Aselsan, Doğuş Otomotiv, Erdemir, Ford Otosan, İçdaş, THY, Tofaş, Turkcell, and Unilever.

\section{Results and Conclusions}

Findings show that the presence of environmentally friendly practices increases the environmentally activist behaviors of employees. The main finding of the second study is that organizations are mostly involved in "attracting talent and being a company preferred by employees" and "reducing the negative effects on employees" in relation to human resources management.

1) When the practices related to human resources management are evaluated in sustainability reporting, it is not possible to confirm that a certain level of social sustainability has been achieved. The rank and importance given to attracting talent leads to the conclusion that a significant portion of the activities that human resources professionals carry out in the name of sustainability serves to sustain the firm's competitive and profitability advantages. In addition to this, the intensity of the data about occupational health and safety, which is a legal requirement, reinforces this view.

2) As a result of the first study, private sector and industrial workers exhibit less environmentally friendly behaviors than the employees in the public sector and other business sectors. As expected, the environmentally friendly practices of the companies increase the environmental behavior of employees, and this is a clear indication of what needs to be done regarding sustainability. Particularly, human resources managers should aim to implement practices that will target pro-environmental employee behaviors.

3) Considering that legal sanctions have increased sustainability practices, it may be advisable to adopt legal regulations for environmental sustainability. Implementations, such as clean energy use, waste management, regulations to encourage water and electricity savings, and a reduction of greenhouse gases, should be mandated by legal regulations, all of which should be aimed to increase employees' pro-environmental behaviors and attitudes. 
Sürdürülebilirlik (sustainability) "kaynakların insanların şimdiki ve gelecekteki ihtiyaçlarını karşılayabilecek hız ve şekilde kullanılması, geliştirilmesi ve korunmasıdır; çevresel, sosyal ve ekonomik nitelikler arasında optimal bir dengenin başarılmasıdır." (Steg, Van Den Berg ve De Groot, 2015; s. 11) Bu tanımdan da anlaşılacağı gibi sürüdürebilirlik insanlar ve çevreleri arasında iyi dengelenmiş bir ilişkiye işaret etmektedir. Diğer bir deyişle, sürüdürülebilir kalkınmayı başarabilmek için üç unsurdan (çevre, toplum, ekonomi) herhangi birisinin, diğer ikisine ket vurmaması gerekmektedir. Bu nedenle, sürdürülebilir bir dünyaya giden dönüşüm sürecinin iş dünyası olmadan tamamlanamayacağı (Doğru, 2012) ve dünyadaki hiçbir gücün iş dünyasının bu süreçte ortaya koyacağı etkiye sahip olamayacağı (Fisk, 2010) açıktır. "Çevreye duyarlı işletme" ve "yeşil işyeri”" yaklaşımları organizasyonları çevresel konulara duyarlı, kaynaklarını etkili bir şekilde kullanan ve sosyal olarak sorumlu olmaya yöneltmiştir (Karaca, 2013; SHRM, BSR, \& Aurosoorya, 2011).

Burada da görüldüğü gibi sürdürülebilirlik, yeşil, çevre yararına, çevreci gibi birden fazla kavram kurumların ekolojik ve sosyal yapıyı korumaya yönelik çaba ve uygulamalarını tanımlamak için kullanılmaktadır. Aralarında, kavramsal olarak farklar olmakla birlikte, kimi zaman sürdürülebilirlik, yeşil ve çevreye yönelik tanımlamalarıyla eş anlamlı olarak kullanılmakta kimi zaman da özünde kaynakların gelecek nesillere kayıpsız bir şekilde aktarımını barındırdığı için daha kapsayıcı bir kavram olarak kabul edilmektedir (Kuşat, 2013).

Çalışanlar hem kendi şirketlerinin çevreye verdiği zarara aracı olmakta hem de bu zararlardan doğrudan etkilenebilmektedirler. $\mathrm{Bu}$ nedenle, organizasyonlardaki çalışanların çevreyi korumaya yönelik tutum ve davranışlarının geliştirilmesi, tüm dünyanın sürdürülebilirliği için kritiktir. Bildirimiz, Türkiye'de şirketlerin sürdürülebilirlik uygulamalarına çalışanlar açısından daha yakından bakmayı hedeflemektedir. Bu amaçla, öncelikle kurumlarda çalışanların çevreye yönelik tutum ve davranışları araştııılmış, ikinci olarak da önde gelen şirketlerin çalışanları başta olmak üzere insan odaklı uygulamaları insan kaynakları yönetimi perspektifinden değerlendirilmiştir.

\section{Sürdürülebilir Çalışma Ortamı}

İnsan ihtiyaçlarını karşılama yeteneğinin devamlı kılınması olarak da tanımlanabilecek olan sürdürülebilir kalkınma, işletmeler açısından düşünüldüğünde kurumsal sürdürülebilirlik kavramı olarak ortaya çıkmaktadır. Kurumsal sürdürülebilirlik, gelişme aşamasında olan yeni bir yönetim değeri olarak betimlenmekte, bunun geleneksel büyüme ve karlılığı en yüksek noktaya çekme modeline alternatif bir yaklaşım olarak ortaya çıktığı belirtilmektedir (Saban, Küçüker ve Küçüker, 2017). Diğer bir deyişle kurumsal sürdürülebilirlik, işletmelerin faaliyetlerini yerine getirirken yol açtıkları sosyal ve çevresel konulara şirketin 
stratejik ve kar odaklı cevap verme şekli olarak tanımlanmıştır. Buna göre kurumsal sürdürülebilirliğin iki temel özelliği, yeni bir iş yapma modeli ve yalnızca şu anki kazanımlara değil, geleceğe de yatırım yapmak olarak belirtilmektedir (Tokgöz ve Önce, 2009).

Amerika Birleşik Devletleri'nde yapılan bir araştırmaya göre (SHRM, BSR, \& Aurosoorya, 2011) organizasyonların \% 75 'inde sürdürülebilirliğe ilişkin uygulamalar yürütülmektedir. Organizasyonların sürdürülebilirliğe ilişkin çabalarını Jabbour ve Santos (2006), üç basamaklı bir model üzerinde açıklamaktadır: 1. Çevreye yönelik yasal düzenlemelere uyum 2. Çevreye verilen zararın engellenmesi ve 3. Uzun dönemli sürdürülebilirlik için korumaya yönelik gönüllü çalışmalar ve değişim. Organizasyonlar, bu uygulamaları hayata geçirmelerinin gerekçelerini; topluma katkıda bulunma, rekabet edebilecek finansal avantaj sağlama, çevreye verilen önem, işletim maliyetlerinden tasarruf etme, para ve çalışanların sağlık ve güvenliğine verilen önem olarak açıklamaktadır. Türkiye'de IMKB sürdürülebilirlik endeksine yönelik faaliyetlerden biri olarak PwC tarafindan 2011 yılında yayınlanan, Türk İş Dünyası'nda Sürdürülebilirlik Uygulamaları Değerlendirme Raporu'na göre, İMKB şirketlerinin hemen hemen tamamının sürdürülebilirlik konusunun şirketlerinin faaliyetleri için önemli olduğunu düşünmesi, 2/3'ünün sürdürülebilirlik konularında stratejilerinin olduğunu beyan etmesi, sürdürülebilirlik raporlaması yapmayan şirketlerin yarıya yakının ilerideki yıllarda raporlama yapmayı düşünmesi Türk işgücü piyasası için umut verici olarak değerlendirilmiş̧ir. Bu raporun ardından da, IMKB Sürdürülebilirlik Endeksi hayata geçmiştir.

İşletmelerin, sürdürülebilirlik girişimlerinden bekledikleri olumlu sonuçların başlıcaları şunlardır: Çalışanların morallerinin artması, işletme süreçlerinin daha etkili hale gelmesi, şirketin kamuoyu nezdinde daha olumlu imajı ve artan marka bilinirliği (SHRM, BSR, \& Aurosoorya, 2011; Zibarras \& Ballinger, 2011). Bu sonuçlardan hiçbirinin doğrudan çevreyle ilgisinin bulunmaması, işletmelerin sürdürülebilirlik konularına olan ilgisine dair motivasyon kaynaklarının çevreye faydalı olmak yerine, işletmeye çeşitli faydalar sağlamak olduğunu düşündürmektedir, ki bu kendi içinde çelişkili bir durum da oluşturmaktadır.

Bir yandan da bu durum, kurumsal sosyal sorumluluk yaklaşımından başlayarak, sürdürülebilirlik uygulamalarının çoğunun şirketlere itibar yönetiminin bir aracı olarak sunulmasının sonucudur. Yapılan araştırmaların dabu sonucu desteklediği görülmektedir. Bir şirketin çevreye duyarlı politikalarla yönetiliyor olması, şirketin adaylar için çekiciliğini, işe girme çabasını ve gelen teklifi kabul etme oranını yükseltmektedir (Bauer, 1996). Çalışma yaşamına yeni adım atmış ya da atacak kuşakların çevresel etkilerini kontrol eden, sosyal faydayı önemseyen şirketleri seçtiği gözlemlenmektedir (Türşen, 2015). Diğer yandan, yeşil girişimleri daha genç kuşakları şirkete çekmek için 
bir strateji olarak, "şirketi yeşile boyayarak", kullanan şirketler olsa da, şirketin gerçek duruşunun böyle olmadığı işe girdikten kısa bir süre sonra anlaşlabilmektedir. Bu nedenle şirketlerin başlangıç düzeyinde de olsa gerçek uygulamalarını duyurmalarında yarar vardır (SHRM, BSR, \& Aurosoorya, 2011). Çevre bilinci olan, topluma katkı sağlayan, sürdürülebilirlik anlayışının egemen olduğu firmalar, çalışan-şirket ilişkisini daha kalıcı ve olumlu bir zemine taşınmaktadır.

\section{Sürdürülebilirlik Raporlaması}

Organizasyonların çevreye olan etkilerini değerlendirdikleri ve çevre yararına olan çalışmalarına yer verdikleri kurumsal sosyal sorumluluk ya da sürdürülebilirlik raporları "yeşil girişim"leri kamuya duyurma işlevini üstlenmektedir. Faaliyetlerini ekonomik başarı yanında çevresel ve sosyal boyutta değerlendiren şirketler için, sosyal sorumluluk raporlaması geleneksel finansal raporlamanın ötesine geçerek işletmenin toplumsal faydalarını da raporlayan ve böylelikle işletme sorumluluklarını genişleten bir fonksiyona sahip olmaktadır (Başar ve Başar, 2006).

Sürdürülebilirlik raporlamaları 1990'lı yıllardan bu yana hem dünyada hem de ülkemizde çeşitli kuruluşlar tarafından oluşturulmaya başlamıştır. 1992 yılında Dünya Sürdürülebilir Kalkınma İş Konseyi (WBCSD) uluslararası 209 şirket ile ekonomik büyüme, çevre dengesi ve sosyal gelişim konularında sürdürülebilir kalkınma üzerine taahhütlerini ortaya koyarak koalisyon oluşturmuştur. Bu Konseyin Türkiye'deki ortağı 2004 yılında kurulan İş Dünyası ve Sürdürülebilir Kalkınma Derneği’dir (Saban, Küçüker ve Küçüker, 2017). Yine 1995 y1lında Avrupa Kurumsal Sosyal Sorumluluk Birliği, kamu-özel sektör-sivil toplum ortaklıklarını temel alan bir yaklaşım ile kurumsal sosyal sorumluluk kavramının uluslararası standartlarda yaygınlaşması amacını güderek kurulmuştur. 2005 yılında kurulan Türkiye Kurumsal Sosyal Sorumluluk Derneği bu kuruluşun üyesidir. 2000 yllında oluşturulan Birleşmiş Milletler Küresel İlkeler Sözleşmesi sürekli rekabet içindeki iş dünyasına ortak bir kalkınma kültürü oluşturmak üzere evrensel ilkeler öneren yenilikçi bir kurumsal sorumluluk yaklaşımıdır. Türkiye'deki ayağı 2002 yılında kurulan Global Compact Türkiye'dir. Bunların yanında Uluslararası Entegre Raporlama Konseyi (2010) ve Sürdürülebilirlik Muhasebesi Standartları Kurulu (2011) da sürdürülebilirlik raporlamalarında önemli kuruluşlar olarak belirtilmektedir (Saban, Küçüker ve Küçüker, 2017).

Sürdürülebilirlikle ilgili başlıca performans göstergeleri Birleşmiş Milletler Küresel İlkeler Sözleşmesi, (UN Global Compact), AA1000APS Hesap Verebilirlik Prensipleri Standardı, OECD Çokuluslu İşletmeler Rehberi, ISO26000 Sosyal Sorumluluk Rehberi Standard1, Karbon Saydamlık Projesi, Entegre Raporlama, FTSE4 Good Endeksi, Küresel Raporlama Girişimi (GRI), Dow Jones Sürdürülebilirlik Endeksi ve Çevresel Sürdürülebilirlik Endeksi'dir (Tokgöz \& Önce, 2009; Saban, Küçüker ve Küçüker, 2017). Tüm bu raporlama ve performans göstergeleri işletmelerin 
ekonomik, çevresel ve sosyal olarak etkilerini ölçümleyip standardize hale getirme amacı taşımaktadır. En yaygın raporlama standartlarından biri olan GRI ilkeleri bugün gerek Türkiye'de gerekse dünyada çok sayıda işletme tarafindan benimsenmiştir. GRI'ın belirlediği performans göstergeleri ekonomik, çevresel ve sosyal olmak üzere 3 bölüme ayrılmıştır (GRI, 2017):

1) Ekonomik Performans Göstergeleri (ekonomik performans, piyasadaki konum, dolaylı ekonomik etkiler)

2) Çevre Performans Göstergeleri (malzemeler, enerji, su, biyoçeşitlilik, emisyonlar, sıv1 ve katı atıklar, ürün ve hizmetler, uyum, ulaştırma, genel)

3) Sosyal Performans Göstergeleri

a. İnsan Hakları Performans Göstergeleri (yatırım ve satın alma uygulamaları, ayrımcılık yapmama, örgütlenme özgürlüğü ve toplu sözleşme, çocuk iş̧̧iliği, zorla veya zorunlu tutarak çalıştırma, güvenlik uygulamaları, yerli hakları)

b. İşgücü Uygulamaları ve İnsana Yakışır İş Performans Göstergeleri (istihdam, işgücü/yönetim ilişkileri, iş sağllğ 1 ve güvenliği, eğitim ve öğretim, çeşitlilik ve fırsat eşitliği)

c. Ürün Sorumluluğu Performans Göstergeleri (müşteri sağllğ̆ ve güvenliği, ürün ve hizmet etiketlemesi, pazarlama iletişimi, müşterinin kişisel gizliliği, uyum)

d. Toplum Performans Göstergeleri (yerel halk, yolsuzluk, kamu politikası, rekabeti kısıtlayan davranış, uyum)

Görüleceği gibi, sürdürülebilirlik raporlarında, İnsan Kaynakları Yönetimi ile ilgili bilgilendirme ve açılamalar ağırlıklı olarak, Sosyal Performans başlığı altında İnsan Hakları ile İşgücü Uygulamaları ve İnsana Yakışır İş Performans Göstergeleri bölümlerinde yeralmaktadır.

\section{Sürdürülebilir İnsan Kaynakları Yönetimi}

Sürdürülebilirlik stratejisinin yaratılması Genel Müdür ve tepe yönetimin sorumluluğu olsa da, bu stratejinin hayata geçirilmesiyle ilgili eğitim, iletişim vb faaliyetler insan kaynakları yönetiminin çalışma alanına girmektedir. Tüm bu gelişmeler sonucunda sürdürülebilirlik konusu insan kaynakları profesyonellerinin gündemlerine girmiştir (Türşen, 2015). Sürdürülebilir IKKY anlayış1; çevre yönetimi, kurumsal sürdürülebilirlik, İKY ve kurumsal sosyal sorumluluk çalışmalarından etkilenerek gelişmektedir. İnsan kaynakları yönetiminin sürdürülebilirliğin izlenmesindeki rolü ve etkisinin artması, araştırmacıları bu konudaki yaklaşım ve günlük uygulamaları daha iyi anlamaya ve açıklamaya yöneltmiştir. Günümüzde sürdürülebilir İKY konusundaki 
araştırmalarda; sürdürülebilir iş sistemleri, sosyal sorumlu İK, yeşil İK vb. kavramların ardından "üçüncü dalga"dan sözedilmektedir. Buna göre interdisipliner ekipler birarada çalışarak, sürdürülebilir İKY sistemlerinden sürdürülebilirliğin toplumsal tartışmasına doğru giden bir yön izlenmektedir (Ehnert ve Harry, 2012).

Sürdürülebilir İKY, geleceğin ihtiyaçlarını karşılama kabiliyetinden ödün vermeden, mevcut şirketin ve toplumun optimum ihtiyaçlarını karşılamak için insan kaynaklarının yönetimi olarak tanımlanmaktadır (Mariappanadar, 2013). Ehnert (2009) şirketlerin sürdürülebilirliği ve sürdürülebilir gelişmeyi nasıl tanımladığını

TABLO 1

Sürdürülebilirlik kategorileri ve ilgili insan kaynaklarl uygulamalart

İnsan kaynaklarını sosyal
sorumlulukla ele alma
- Etik ve çalışanlarla yakından ilgi-
lenme
- İşini kaybedenleri destekleme

Yeteneği cezbetme ve "çalışanların tercih ettiği bir şirket" olarak tanınma

- Çalışanlara, ve onların yetenekleriyle bilgilerine yatırım yapma

- Kariyer olanakları sunma

- Cazip ve aynı zamanda zorlayıcı bir iş ortamı sunmak

- Kültürel çeşitliliği ve cinsiyet eşitliğini sağlama

- Sosyal olarak sorumlu ve güvenilir bir işveren olmanın yanı sıra, işyerinin itibarını aile dostu ve çalışan annelerin yanında bir şirket olarak güçlendirme

- İş ve iş dışı yaşam dengesinin önemine dikkat çekme

- Yedekleme planları, yetenek havuzu

- İş tatmini ve motivasyon

- Ücretlendirme ve ek sosyal olanaklar

Çalışan sağlığg ve esenliğini destekleme

- Çalışma yaşamının kalitesini iyileştirme

- Çalışanlarda kendi sağlıklarıyla ilgili farkındalık yaratma

- Sağlıklı bir yaşam tarzını teşvik etme

- İşgücünün formda olmasını sağlama

- Çalışanların ve ailelerinin esenliğini destekleme

- İş ve iş dışı yaşam dengesini teşvik etme

Çalışanlar üzerindeki negatif etkilerin azaltılması

- İş sağlığ1 ve güvenliği: iş kazaları, yaralanmalar ve ölümcül kazalar riskini azaltma

- Meslek hastalıkları riskini azaltmak için ergonomik çalışma koşullarını iyileştirme

- Stresi önlemek ve azaltma

Çalışanların yaşam standartlarını

iyileştirme

- Sağlıklı bir yaşam tarzını teşvik etme

- İş ve iş dışı yaşam dengesini teşvik etme

Kaynak: Ehnert, I. (2009). Sustainability and human resource management: reasoning and applications on corporate websites. European J. International Management,3(4), 419-438., S: 433
Mevcut çalışanların becerilerine yatırım yapma

- Eğitime yatırım

- Yaşam boyu öğrenmeyi destekleme

- Çalışan gelişimi ve eğitim programları

- Mesleki eğitim programları ve çıraklık

- Yetenek yönetimi ve kariyer yönetimi programları

- Çalışanlar ve yöneticiler için kariyer gelişimi

- Mentorluk
İnsan Kaynaklarının özüne yatırım yapma

- Eğitime, staja yatırım yapma

- Yaşam boyu öğrenmeyi güçlendirme

- Üniversitelerle işbirliği

- Yedekleme planları, yetenek havuzu

Karşılıklı güvenilir ilişkiler kurma

- Çalışanların güvenini kazanma ve sürdürülebilir ilişkileri yaratma 
ve bunu insan kaynaklarının yönetimine nasıl bağladıklarını incelediği çalışmasında şirketlerin sürdürülebilirlikle ilişkili faaliyetlerini sekiz temel başlıkta toplamaktadır: a) İnsan kaynaklarını sosyal sorumlulukla ele alma, b) çalışan sağlığı ve esenliğini destekleme, c) çalışanlar üzerindeki negatif etkilerin azaltılması, d) yeteneği cezbetme ve "çalışanların tercih ettiği bir şirket" olarak tanınma, e) mevcut çalışanların becerilerine yatırım yapma, f) İnsan Kaynaklarının kökenine yatırım yapma, g) çalışanların yaşam standartlarını iyileştirme, h) karşılıklı güvenilir ilişkiler kurma. Bu sekiz ana başlığın neleri içerdiği Tablo 1'de gösterilmektedir:

Çalışanların kurumsal vatandaşlık olarak sayılacak bazı yeşil davranışları (örnek olarak, çalışırken yaptığı herhangi bir işin çevreye zarar verip vermeyeceğini sorgulama gibi) insan kaynakları yönetimi uygulamaları ile işletmenin çevre performansı arasında aracılık etmektedir. Bir başka deyişle, bu davranışların varlığı insan kaynakları yönetimini çevresel açıdan etkili hale getirmektedir (Paille, Chen, Boiral, \& Jin, 2014). Çalışanlar tarafından en önemli görülen ve insan kaynakları yönetimlerince sürdürülen çevresel sorumluluk uygulamaları şunlardır: a) Kullanılmış ofis mobilyası ya da eşyalarını, yardım derneklerine bağışlamak ya da çalışanlara indirimli olarak verme b) Yürüyüş, bisiklete binme ve toplu ulaşımı kullanmayı teşvik etme c) Enerji tasarruflu ışıklandırma sistemi ve/veya ekipmanı kullanma d) Çalışanları işyerinde daha çevre dostu olmaları yönünde teşvik etme e) Çalışanları araba paylaşımı konusunda destekleme, teşvik etme. (SHRM, BSR, \& Aurosoorya, 2011).

Bir işletmede çevre yararına sonuçlar, şirket içinde çevresel yönelimin çalışanlarca iyi anlaşılması ve çalışanların çevreci davranışlarının artmasıyla ortaya çıkmaktadır (Paille, Chen, Boiral, \& Jin, 2014). Bu nedenle, insan kaynakları yönetimi uygulamalarıyla çevresel performans arasındaki ilişkiyi kurabilmek için o işyerinde hangi çevre yararına davranışların gerekli olduğunun belirlenmesi önceliklidir. Böylelikle bir şirkette çalışanlar, şirketlerinin daha "yeşill" olması için neyi nasıl yaptıkları ve sürdürülebilirliğe hangi durumda katkıda bulunduklarını daha iyi anlayacaklardır.

\section{Sürdürülebilir Çalışma}

Çalışanların sürdürülebilirlikle ilgili davranışlarından İngilizce yazında sıklıkla, "çevre yararına", "çevre dostu ve "yeşil" olarak söz edilmekte, "sürdürülebilir davranış" tanımlaması da aynı zamanda kullanılmaktadır (Kuşat, 2013; Davis, 2013). Ones ve Dilchert (2012)'e göre yeşil davranışlar, çallşanların çevresel sürdürülebilirlik için katkı sağladıklarl ya da yapmaktan vazgeçtikleri, ölçülebilir eylem ve davranışlardır. Çalışanların çevre yararına yaptıkları davranışlar beşli bir sınıflandırmayla açıklanmaktadır (Tablo 2): 
Tablo 2

Çalışanların yeşil davranışları beşli sınıflandırma

\begin{tabular}{|c|c|}
\hline $\begin{array}{l}\text { Zarar vermekten } \\
\text { kaçınma }\end{array}$ & $\begin{array}{l}\text { - Hava kirliliğini önleme } \\
\text { - Çevresel etkisini izleme } \\
\text { - Eko sistemi koruma ve destekleme }\end{array}$ \\
\hline Koruma & $\begin{array}{l}\text { - Kullanımı azaltma } \\
\text { - Yeniden kullanma } \\
\text { - Yeniden değerlendirme, geri dönüşüm } \\
\text { - İşin yapılış şeklini değiştirme }\end{array}$ \\
\hline $\begin{array}{l}\text { Sürdürülebilirlik } \\
\text { için çalışma }\end{array}$ & $\begin{array}{l}\text { - Çevreye karşı daha duyarlı / sorumlu seçeneklerle değiştirme } \\
\text { - Sürdürülebilir ürün ve işlemler yaratma } \\
\text { - Sürdürülebilirlik için yeniliklere kucak açma }\end{array}$ \\
\hline Etkileme & $\begin{array}{l}\text { - Diğer kişileri teşvik etme ve destekleme } \\
\text { - Sürdürülebilirlik için eğitme ve yetiştirme }\end{array}$ \\
\hline $\begin{array}{l}\text { Çevre için } \\
\text { inisiyatif alma }\end{array}$ & $\begin{array}{l}\text { - Çevresel öncelikleri ilk sıraya koyma } \\
\text { - Çevre yararına, eylem ve lobi faaliyetlerinde bulunma, program ve politikaları başlatma }\end{array}$ \\
\hline
\end{tabular}
Kaynak: McConnaughy, J.C. "Development of an employee green behavior descriptive norms scale" (2014).

Çalışanların çevre yararına olan davranışları ile yaşam değerleri arasındaki ilişkiyi araştıran bir çalışmaya göre (Kılıç ve Vatansever, 2017); en güçlü ilişkiler çevreyi "koruma tutumu" ve "çaba gösterme" davranışı ile evrensellik değeri arasındadır. Bu bulgu, evrensellik değerinin, "insanların doğayı korumaları gerektiğine gönülden inanma; çevreye bakıp güzelleştirmeye önem verme" yi içermesiyle açıklanmaktadır. Çalışmada, "çevresel sorunların abartıldığını, ve gelecekte her şeyin daha iyi olacağını" içeren statükocu tutumla evrensellik değerinin olumsuz ilişki içinde olduğunun bulunması, çevreci yaklaşımın insanlığa daha geniş ve eşitlikçi bir çerçeveden bakan evrensellik değeri ile doğrudan ilişkili olduğunun bir göstergesi olarak değerlendirilmiştir.

Çalışmamızda, Türkiye'deki işyerleri ve çalışma ortamlarında sürdürülebilirlik açısından nelerin var olduğunu ve nasıl ele alındığını anlamak amaçlanmıştır. Bu amaçla bildiri, iki ayrı çalışmanın yazını ve bulgularını ilişkilendirilerek Türkiye'de insan kaynakları yönetimi'nin sürdürülebilirlikteki rolünü tanımlayıp tartışmayı amaçlamaktadır. Birinci araştırma, çalışanların çevre yararına olan davranışlarını anlamaya ve açıklamaya yöneliktir. Türkiye'nin önde gelen şirketlerinde insan kaynaklarının sürdürülebilirliğine ilişkin neler yapıldığı ve insan kaynakları yönetimi adına yürütülen sürdürülebilirlik uygulamalarının neler olduğuna yanıt bulmak ise ikinci çalışmanın kapsamını oluşturmaktadır.

Bu kapsamda oluşturulmuş araştırma soruları şunlardır:

a) Türkiye'de işyerlerinde çevreyi korumaya yönelik uygulamalar nelerdir? (Çalışma I )

b) İşyerlerinde çevreye yönelik uygulamalar ile çalışan davranışları arasında nasıl bir ilişki vardır? (Çalışma I )

c) Türkiye'de sürdürülebilirlik uygulamalarında en öncü şirketlerde insan kaynaklarının sürdürülebilirliğine ilişkin neler yapılmaktadır ?(Çalışma II ) 
d) İnsan kaynakları yönetimi fonksiyonlarıyla sürdürülebilirlik arasında nasıl bir ilişki vardır? (Çalışma II)

\section{Yöntem}

\section{Çalışma I}

Geniş bir araştırmanın bir kapsamı olan bu çalışmanın örneklemini, 623 özel sektör ve 212 kamu sektörü olmak üzere farklı iş alanlarında çalışan, 418 kadın ve 417 erkek, toplam 835 kişi oluşturmaktadır.

\section{Ölçme Araçları}

Araştırmada, Topçu, Gazeloğlu ve Yılmaz (2015)'ın geliştirdiği soru formu çalışma yaşamı açısından gözden geçirilerek kısa iki ayrı forma dönüştürülerek kullanılmıştır. Yeşil Tutum Ölçeği: Çevreye yönelik bir dizi farklı tutumu betimleyen ve bireylerin çevreye ilişkin tutumlarını değerlendirmeyi amaçlayan ölçek 17 maddeden oluşmaktadır. Çevre kirliliği, nesillerin yok olması, ekonomi ve çevre ilişkisi, yasama, vb konulardaki çeşitli tutum ve inançları betimlemektedir. Yapılan faktör analizleri sonucu (Kılıç ve Vatansever, 2017) Yeşil Tutum ölçeğinin iki alt boyut ile varyansın $\%$ 42 >sini açıkladığ görülmektedir. Elde edilen alt boyutlar «korumacı tutum» (11 madde, $\alpha=, 83)$ ve «statükocu tutum» (6 madde, $\alpha=, 75)$ olarak adlandırılmıştır. Yeşil Davranış Ölçeği: Bireylerin çevreye ilişkin davranışlarını değerlendirmeyi amaçlayan ölçek 23 maddeden oluşmakta, damlatan muslukları tamir etmekten, doğayı kirletenleri yetkili makamlara şikayet etmeye kadar çevreye yönelik bir dizi çevre dostu davranışı betimlemektedir. Her iki ölçekte de katılımcılar her bir maddeyi "5 = (Tamamen uygun) ve $1=$ (Hiç uygun değil)" beşli skala üzerinden kendilerine uygun seçeneği işaretleyerek yanıtlamışlardır. Yeşil davranış ölçeğine uygulanan faktör analizleri sonucunda üç faktör yapısı ortaya çıktığı, varyansın \% 54,3 kadarını açıkladığı görülmektedir (Kılıç ve Vatansever, 2017). Elde edilen alt boyutlar "çaba gösteren" (11 madde, $\alpha=, 90)$, "yeşil yaşayan" (7 madde, $\alpha=, 81)$ ve "aktivist" ( 5 madde, $\alpha=, 82$ ) olarak adlandırılmıştır.

Ayrıca, katılımcılara "çalışılan işyerinde çevreci uygulamalara önem verme"ye ilişkin bir soru ile "çalıştıkları işyerlerinde çevreye zarar vermemek, doğayı korumak adına hangi faaliyetler yapıldığı" açık uçlu olarak sorulmuştur. Anket formunda yeralan çalışılan işyerinin sektörü, yirmi farklı iş kolu olarak bir liste ile sunulmuş ve dört genel gruba ayrılarak analizler yapılmıştır: Endüstri (enerji, kimya, petrol ve ilgili işkolları, madencilik, tekstil, vb.) , Hizmetler (finans, turizm, satış-pazarlama, vb.), Teknoloji (bilgi teknolojileri, iletişim, vb.) ve diğerleri. 


\section{Bulgular}

Yeşil tutum ve Yeşil Davranışlar ölçeklerinin ölçek ve alt ölçeklerin tutarlılık düzeylerini belirlemek amacıyla Cronbach Alpha güvenirlik analizleri, değişkenler arası ilişkileri belirlemek amacıyla korelasyon analizi, çeşitli gruplar arasındaki farklılıkları belirlemek amacıyla ise t-testi ve ANOVA yapılııştır.

Değişkenler arası ilişkileri görmek amacıyla korelasyon analizi yapılmıştır. Elde edilen sonuçlara göre, çalışılan işyerinde çevreci uygulamalara önem verilme derecesi, çevre konusunda çaba gösterme $(\mathrm{r}=, 56)$, korumacı tutum içinde olma ( $\mathrm{r}$ $=, 47)$, yeşil davranışları gösterme (yeşil yaşama) $(r=, 34)$ ve çevre için aktivist davranışlar gösterme $(r=, 34)$ ile olumlu yönde, statükocu tutum ile olumsuz yönde $(\mathrm{r}=-, 11)$ istatistiki olarak anlamlı korelasyon göstermiştir.

Tablo 3

Yaş, çalışılan işyerinin çevre duyarlılığını önemseme derecesi, çevreye ilişkin tutum ve davranış boyutları arasindaki korelasyonlar

\begin{tabular}{|c|c|c|c|c|c|c|c|c|c|}
\hline & Ort & SS & 1 & 2 & 3 & 4 & 5 & 6 & 7 \\
\hline 1- Yaş & 31,86 & 9,20 & 1 & & & & & & \\
\hline 2- İş yerinin çevre duyarlılığını önemseme & 3,98 & 1,17 &, $10^{* *}$ & 1 & & & & & \\
\hline 3- Çaba gösteren & 4,20 & ,77 &, $13^{* *}$ &, $56^{* *}$ & 1 & & & & \\
\hline 4- Yeşil yasayan & 3,08 & ,94 &, $12^{* *}$ &, $34^{* *}$ &, $39^{* *}$ & 1 & & & \\
\hline 5- Aktivist & 3,37 & ,95 &, 05 &, $34^{* *}$ &, $45^{* *}$ &, $53^{* *}$ & 1 & & \\
\hline 6- Korumaci tutum & 3,99 &, 72 & 07 &, $47^{* *}$ &, $68^{* *}$ &, $23^{* *}$ &, $31^{* *}$ & 1 & \\
\hline 7- Statükocu tutum & 2,59 &, 92 &,$- 08^{*}$ &,$- 11^{* * *}$ & $-23^{* *}$ &, $12^{* *}$ &, $08^{*}$ &,$- 25^{* *}$ & 1 \\
\hline
\end{tabular}

Çalışanların yeşil tutum ve davranışlarında özel sektör / kamu sektörü ayrımına dayalı farklılıklar olup olmadığını görmek amacıyla da analizler yapıldı. Buna göre, işkolları bakımından özel sektör ve kamu sektörü ayrımı, yalnızca çevreyi korumaya yönelik çaba gösterme davranışları ile korumacı tutumlarda ortaya çıkmıştır. Çevreyi korumaya yönelik çaba gösterme davranışları bakımından endüstri alanlarında yer alan özel sektör çalışanları en düşük puanları alırken, kamu sektöründe yer alan endüstri ve teknoloji çalışanları korumacı tutumlar bakımından yükssek puanlar almışlardır.

Tablo 4

Çalışanların yeşil tutum ve davranışlarında özel sektör / kamu sektörü karşılaştırması

\begin{tabular}{lllccccc}
\hline Sahiplik & Değişkenler & Sektör Grupları & $\mathbf{N}$ & Ort. & Std. Sap. & F/Welch & p \\
\hline \multirow{4}{*}{ Özel } & Endüstri & 172 & 4,05 & 0,91 & & \\
& \multirow{3}{*}{ Çaba Gösterme } & Hizmetler & 217 & 4,16 & 0,79 & & \\
& & Teknoloji & 69 & 4,17 & 0,72 & $3,756^{\text {a }}$ & 0,011 \\
& & Diğer & 165 & 4,33 & 0,71 & & \\
\hline \multirow{4}{*}{ Kamu } & Koplam & 623 & 4,17 & 0,80 & & \\
& \multirow{2}{*}{ Korumacı Tutum } & Endüstri & 14 & 3,51 & 1,25 & & \\
& & Hizmetler & 78 & 3,32 & 0,83 & & \multirow{2}{*}{0,006} \\
& & Teknoloji & 18 & 3,62 & 1,02 & $4,255^{\text {b }}$ & \\
\hline
\end{tabular}

$a:$ Welch; $b: F$ 
Çalışanların yeşil tutum ve davranışlarında, çalıştıkları sektörlere göre bir farklılık olup olmadığını anlamak için yapılan analizlerde elde edilen sonuçlara göre; çevreye yönelik korumacı tutuma sahip olma bakımından endüstri işkollarında çalışanlar en düşük, hizmet işkollarında çalışanlar en yüksek puanları almışlardır (Bknz: Tablo 4). Öte yandan, statükocu tutum sahip olma bakımından endüstri işkollarında çalışanlar en yüksek, diğer kategorisinde yer alan çalışanlar en düşük puanları almışlardır. Çevreyi koruma davranışlarına (yeşil davranış) baktığımızda ise çalışanların çaba gösterme davranışlarında sektörler arasında farklılıklar olduğu, yeşil yaşama ve aktivist davranışların sektörlere göre farklılaşmadığı bulunmuştur. Buna göre endüstri sektöründe çalışanlar en düşük çaba gösterme davranışları gösterirken, 〈diğer〉 kategorisinde yer alan çalışanlar en yüksek çaba gösterme davranışları rapor etmişlerdir.

Tablo 5

Çalışanların yeşil tutum ve davranışlarının, çalıştıkları sektörlere göre karşılaştırılması

\begin{tabular}{|c|c|c|c|c|c|c|c|}
\hline \multicolumn{2}{|l|}{ Değișkenler } & \multirow{2}{*}{$\begin{array}{l}\text { Sektör Grupları } \\
\text { Endüstri }\end{array}$} & \multirow{2}{*}{$\frac{\mathbf{N}}{186}$} & \multirow{2}{*}{$\begin{array}{l}\text { Ort. } \\
4,06\end{array}$} & \multirow{2}{*}{$\frac{\text { Std. Sap. }}{0,90}$} & \multirow[t]{2}{*}{ F/Welch } & \multirow[t]{2}{*}{$\mathbf{p}$} \\
\hline \multirow{5}{*}{ Davranışlar } & \multirow{5}{*}{ Çaba Gösterme } & & & & & & \\
\hline & & Hizmetler & 295 & 4,19 & 0,75 & \multirow{4}{*}{$3,445^{\mathrm{a}}$} & \multirow{4}{*}{0,017} \\
\hline & & Teknoloji & 87 & 4,23 & 0,70 & & \\
\hline & & Diğer & 267 & 4,31 & 0,72 & & \\
\hline & & Toplam & 835 & 4,20 & 0,78 & & \\
\hline \multirow{10}{*}{ Tutumlar } & \multirow{5}{*}{ Korumac1 Tutum } & Endüstri & 186 & 3,87 & 0,79 & \multirow{5}{*}{$2,854^{\mathrm{b}}$} & \multirow{5}{*}{0,036} \\
\hline & & Hizmetler & 295 & 4,04 & 0,70 & & \\
\hline & & Teknoloji & 87 & 3,94 & 0,67 & & \\
\hline & & Diğer & 267 & 4,04 & 0,70 & & \\
\hline & & Toplam & 835 & 3,99 & 0,72 & & \\
\hline & \multirow{5}{*}{ Statükocu Tutum } & Endüstri & 186 & 2,73 & 0,97 & \multirow{5}{*}{$4,813^{\mathrm{a}}$} & \multirow{5}{*}{0,003} \\
\hline & & Hizmetler & 295 & 2,65 & 0,96 & & \\
\hline & & Teknoloji & 87 & 2,55 & 0,93 & & \\
\hline & & Diğer & 267 & 2,43 & 0,81 & & \\
\hline & & Toplam & 835 & 2,59 & 0,92 & & \\
\hline
\end{tabular}

$a:$ Welch; $b: F$

Çalışanların işyerlerinde gerçekleştirilen çevreye duyarlı uygulamalara verdikleri önem derecesine göre de çevreye yönelik tutum ve davranışlara ilişkin karşılaştırmalar yapıldı. Bu değişken yüksek önem derecesi ve düşük önem derecesi olarak iki gruba ayrıldı. Orta derecede önem seviyesi analiz dışı bırakıldı. Elde edilen bulgulara göre, çalışanlar işyerlerinde çevreye duyarlı uygulamaları önemseme derecelerine göre çevreye ilişkin tutum ve davranışlarında farklılık göstermektedirler. Buna göre, işyerlerindeki çevreci uygulamalara yüksek derecede önem veren çalışanlar daha fazla çevre yanlısı tutum ve davranış göstermekte, buna karşılık daha düşük düzeyde statükocu tutum sergilemektedirler. 
Tablo 6

Çalışanların işyerlerinde gerçekleştirilen çevreye duyarlı uygulamalara verdikleri önem derecesine göre karşılaştırılması

\begin{tabular}{|c|c|c|c|c|c|c|}
\hline & $\begin{array}{l}\text { İşyerinin çevre duyarlılığını } \\
\text { önemseme derecesi }\end{array}$ & $\mathbf{N}$ & Ort. & Std. Sap. & t dĕgeri & p dĕgeri \\
\hline \multirow{2}{*}{ Çaba Gösterme } & Düşük önem & 109 & 3,27 & 1,12 & \multirow{2}{*}{$-10,690$} & \multirow{2}{*}{, 000} \\
\hline & Yüksek önem & 603 & 4,44 & ,49 & & \\
\hline \multirow{2}{*}{ Yesil Yaşama } & Düşük önem & 109 & 2,52 & ,92 & \multirow{2}{*}{$-7,652$} & \multirow{2}{*}{, 000} \\
\hline & Yüksek önem & 603 & 3,25 & ,92 & & \\
\hline \multirow{2}{*}{ Aktivist } & Düşük önem & 109 & 2,81 & 1,06 & \multirow{2}{*}{$-6,815$} & \multirow{2}{*}{, 000} \\
\hline & Yüksek önem & 603 & 3,55 &, 88 & & \\
\hline \multirow{2}{*}{ Korumacı Tutum } & Düşük önem & 109 & 3,25 & 1,00 & \multirow{2}{*}{$-9,384$} & \multirow{2}{*}{, 000} \\
\hline & Yüksek önem & 603 & 4,18 &, 53 & & \\
\hline \multirow{2}{*}{ Statükocu Tutum } & Düşük önem & 109 & 2,96 & ,97 & \multirow{2}{*}{4,189} & \multirow{2}{*}{, 000} \\
\hline & Yüksek önem & 603 & 2,54 & ,91 & & \\
\hline
\end{tabular}

Çalışılan işyerinde çevre dostu uygulama olup olmamasına göre çevreye ilişkin davranış ve tutumlardaki farklılıklara bakıldığında ise, işyerlerinde çevre dostu uygulamalar olduğunu belirten çalışanların çevre konusunda aktivist davranışları daha fazla gerçekleştirdiği görülmektedir. Soru formunda açık uçlu olarak yer alan "Çalıştıkları işyerlerinde çevreye zarar vermemek, doğayı korumak adına hangi faaliyetler yapıldığı"na ilişkin veriler incelendiğinde, çalışmaya katılan 895 çalışandan 428'inin (katılımcıların \% 48'i) bu faaliyetlerin neler olduğunu belirttiği görülmektedir. Tablo 7'den de izlenebileceği gibi, işyerlerinde en fazla "geri dönüşüm" konusunda faaliyet gösterildiği belirtilmiştir (\% 67). Bunu sırasılya "yeşil alan düzenleme" (\% 8) ve "malzeme kullanımı ile ilgili uygulamalar" (\% 6) izlemektedir. Dikkat çekici olan bir unsur ise, bu soruya yanıt veren katılımcıların yalnızca \% 1'nin “enerji tasarrufu” uygulamasından bahsetmiş olmasıdır.

Tablo 7

Issyerlerindeki çevre dostu uygulamalar

\begin{tabular}{lcc}
\hline Uygulama & Sıklık & Yüzde \\
\hline Geri dönüşüm & 287 & $67 \%$ \\
Birden fazla uygulama olması & 44 & $10 \%$ \\
Yeşil alan düzenleme & 33 & $8 \%$ \\
Malzeme kullanımı & 27 & $6 \%$ \\
Geri dönüşüm ve enerji tasarrufu & 12 & $3 \%$ \\
Eğitim- seminer-gezi-projeler & 11 & $3 \%$ \\
Enerji tasarrufu & 5 & $1 \%$ \\
Çevresel denetim & 3 & $1 \%$ \\
Çevre yararına bağış & 3 & $1 \%$ \\
Hayvan dostu uygulama & 3 & $1 \%$ \\
\hline TOPLAM & $\mathbf{4 2 8}$ & \\
\hline
\end{tabular}

\section{Çalışma II}

Türkiye'nin önde gelen şirketlerinde insan kaynaklarının sürdürülebilirliğine ilişkin neler yapıldığı ve insan kaynakları yönetimi adına yürütülen sürdürülebilirlik 
uygulamalarının neler olduğuna yanıt bulmak ikinci çalışmanın kapsamını oluşturmaktadır. Böylelikle, Türkiye'nin çalışma yaşamının yönünü belirleyen büyük şirketlerin sosyal performans göstergelerini analiz ederek bu alandaki eğilimleri ortaya koymak ve Türkiye'deki uygulamalara 1şık tutmak hedeflenmiştir.

Yukarıda belirtilen araştırma soruları kapsamında şirketlerin belirlenmesi için sürdürülebilirlik raporu yayınlayan ancak BİST Sürdürülebilirlik Endeksi kapsamında yer almayan çok sayıda şirket bulunması nedeniyle, Fortune Türkiye 50 listesi tercih edilmiştir. ABD orijinli saygın bir iş dergisi olan Fortune, 1955 yılından itibaren dünyanın en büyük şirketlerini açıkladığı "Fortune 500" listesini yayınlamaktadır (Yılmaz, 2015). Türkiye'de 2007 yılında yayın hayatına başlayan Fortune dergisinin net satış büyüklüklerine göre sıraladığı ve ilk 50 'de yer alan şirketler araştırma kapsamına alınmıştır.

Fortune 50 listesinde yer alan şirketlerin güncel sürdürülebilirlik raporları değerlendirmesini amaçlayan araştırmamız kapsamında işletmelerin web siteleri incelenerek İnsan Kaynakları ve/veya Sürdürülebilirlik sayfalarına erişilmiş ve böylelikle 2016 yılına ait Sürdürülebilirlik Raporları temin edilmiştir.

Ocak 2018'de yürütülen veri oluşturma sürecinde, listedeki şirketlerden 13 tanesinin herhangi bir faaliyet ya da sürdürülebilirlik raporu paylaşmadığı, kalan 37 şirketten yalnızca 11'inin güncel 2016 yılı Sürdürülebilirlik Raporu'nu yayınladığı görülmüştür. Araştırma kapsamında analiz için seçilen bu 11 şirket aynı zamanda son üç yıldır sürdürülebilirlik raporlarını zamanında ve düzenli olarak yayınlamaktadır: Arçelik, Anadolu Efes, Aselsan, Doğuş Otomotiv, Erdemir, Ford Otosan, İçdaş, THY, Tofaş, Turkcell ve Unilever.

\section{Örneklem}

Araştırmaya konu olan işletmelerin tümü özel sektör işletmesi olup 9 ayrı sektörde faaliyet göstermektedirler. Türk Hava Yolları A.O. (5) seyahat ve taşımacılık hizmetleri; Arçelik A.Ş. (12) elektrikli ev aletleri; Ereğli Demir ve Çelik Fabrikaları T.A.Ş. (16) ile İçdaş Çelik Enerji Tersane ve Ulaşım Sanayi A.Ş. (28) metal döküm ve işleme; Doğuş Otomotiv Servis ve Ticaret A.Ş. (15) motorlu taşıt satış ve servisi; Ford Otomotiv Sanayi A.Ş. (8) ile Tofaş Türk Otomobil Fabrikası A.Ş. (13) taşıt araçları ve ekipmanları imalat ve bakımı, Anadolu Efes Biracılık ve Malt Sanayi A.Ş. (19) endüstriyel gıda imalatı, Aselsan Elektronik San. ve Tic. A.Ş. (41) elektronik ve telekomünikasyon, Turkcell İletişim Hizmetleri A.Ş. (14) bilgi ve iletişim hizmetleri ve Unilever Sanayi ve Ticaret Türk A.Ş. (34) toptan gida içecek ve temizlik ürünleri sektöründe yer almaktadır. Şirketlerin Fortune listesindeki sıralamaları ise her şirketin isminin ardından parantez içinde verilmiştir. 


\section{Analiz}

Analiz için, şirketlerin sürdürülebilirlik raporlarında insan kaynaklarıyla ilgili bölümler seçilerek veri seti oluşturulmuştur. İçerik analizi için Ehnert(2009) tarafından oluşturulan (Tablo 1) "İKY ile ilişkili sürdürülebilirlik kategorileri” kod listesi olarak kullanılmıştır. Kod listesindeki her bir kategori, iki değerlendirici tarafindan ayrı ayrı sürdürülebilirlik raporunda olup olmadığına bakılarak varsa rapordaki ifade (açıklama, uygulama örneği vb.) kaydedilerek veri seti oluşturulmuştur. Kodlamalar tamamlandıktan sonra farklılıklar belirlenerek değişiklik ve düzeltmeler yapılarak kod tablosuna son şekli verilmiştir.

\section{Bulgular}

Tablo 8'de araştırma kapsamındaki şirketlerin 2016 yılı çalışan sayıları verilmiştir. Yaklaşık 30 bin çalışan ile en büyük istihdam yaratan şirket Arçelik olurken, yaklaşık 2 bin 500 kişilik çalışan sayısı ile en küçük ölçekli şirket Doğuş Otomotiv olarak belirlenmiştir.

\section{Toplam Çalışan Sayısı 2016}

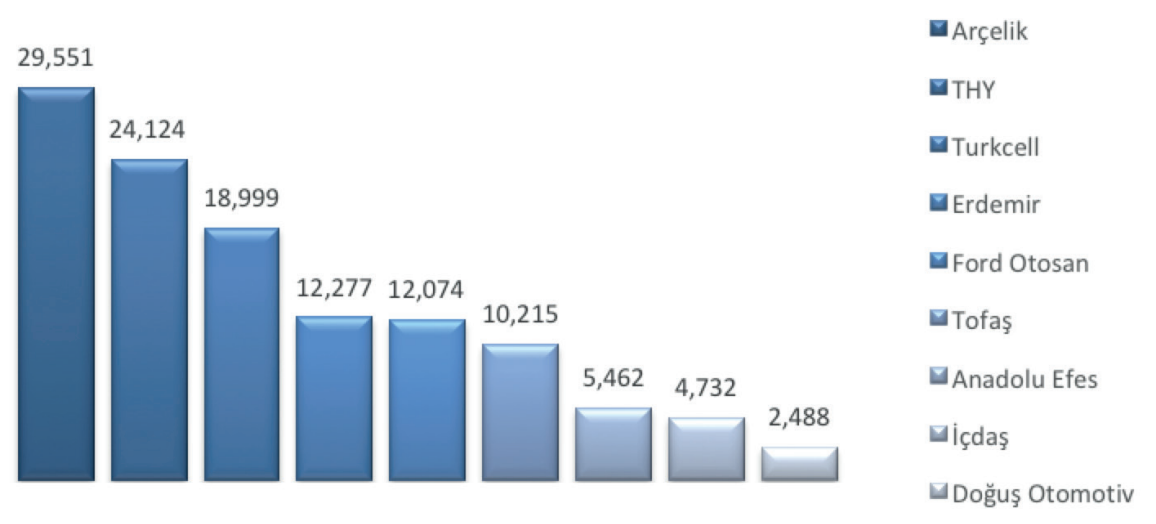

(*) Aselsan ve Unilever'in raporlarında çalışan sayılarına ilişkin bilgi bulunmadığından iki şirkete tabloda yer verilememiştir.

\section{İnsan Kaynakları Yönetimi Verisinin İçerik Analizi}

Analiz için, şirketlerin sürdürülebilirlik raporlarında insan kaynaklarıyla ilgili bölümler seçilerek veri seti oluşturulmuştur. Tablo 9' da analiz kapsamında incelenen 11 adet sürdürülebilirlik raporunun toplam sayfaları ile insan kaynaklarına ayrılan sayfa sayısı listelenmiştir. 
Tablo 9

Araştırma kapsamındaki şirketlerin toplam sürdürülebilirlik raporu ve ik ile ilgili sayfa sayıları

\begin{tabular}{lccc}
\hline Şirket & Sayfa Sayısı & İK Sayfa Sayısı & Sayfa Sayısı $\%$ \\
\hline Arçelik & 81 & 10 & $12 \%$ \\
Doğuş Otomotiv & 92 & 7 & $8 \%$ \\
Erdemir & 82 & 10 & $12 \%$ \\
Ford Otosan & 122 & 15 & $12 \%$ \\
THY & 110 & 15 & $14 \%$ \\
Tofaş & 70 & 6 & $9 \%$ \\
Anadolu Efes & 64 & 7 & $11 \%$ \\
Turkcell & 79 & 12 & $15 \%$ \\
Aselsan & 49 & 17 & $35 \%$ \\
İçdaş & 90 & 6 & $7 \%$ \\
Unilever & 10 & 0 & 0 \\
\hline TOPLAM & $\mathbf{8 4 9}$ & $\mathbf{1 0 5}$ & \\
\hline
\end{tabular}

Unilever kapsamlı bir sürdürülebilirlik raporu oluşturmak yerine özet bir rapor halinde faaliyetlerini paylaşmış; rapor kapsamında insan kaynakları, tedarik zinciri vb gibi ayrımlara gidilmemiştir. İnsan kaynakları özelinde bilgi paylaşılan bir bölüm bulunmaması sebebiyle veri analizinde insan kaynaklarına ayrılan sayfa sayısı 0 olarak gösterilmişti

Yüzdesel olarak bakıldığında rapor genelinde insan kaynaklarına en fazla yer veren şirket \%35 ile Aselsan olarak görünmektedir. Aselsan'1 takip eden Turkcell ve THY ise sirasıyla tüm raporun $\% 15$ ve $\% 14$ 'lük bir kısmını insan kaynakları uygulamalarından bahsetmeye ayırmıştır. Diğer şirketler \%10 bandında seyrederek, $\% 12$ ila \%7 aralığındaki bir kısımda insan kaynaklarından söz etmişlerdir.

Toplam 11 şirketten 9'u raporlarına "Sürdürülebilirlik Raporu" adını verirken; Doğuş Otomotiv "Kurumsal Sürdürülebilirlik Raporu; Unilever ise "Sürdürülebilir Yaşam Planı" adı ile raporlarını paylaşmıştır.

\section{Kriter Bazında İçerik Analizi}

İçerik analizinde kullanılan Ehnert'in kod listesine göre yapılan analizde, toplam 431 kodlama yapılmıştır. Yapılan kodlamaların sıklığı, sürdürülebilirlik raporlarında o kategoriye ne kadar çok yer verildiğini göstermektedir. Bu 431 kodun, kategorilere göre dağılımı Tablo 10’te gösterilmektedir: 
Tablo 10

Sürdürülebilirlik kategorilerine göre insan kaynakları uygulamalarının dağılımı

\begin{tabular}{lcc}
\hline Kategoriler & Sıklık & Yüzde \\
\hline Yeteneği cezbetme ve “çalışanların tercih ettiği bir şirket” olarak tanınma & 143 & $33 \%$ \\
\hline Çalışanlar üzerindeki negatif etkilerin azaltılması & 71 & $16 \%$ \\
\hline Mevcut işgücünün becerilerine yatırım yapma & 64 & $15 \%$ \\
\hline Çalışan sağlı̆̆ı ve esenliğini destekleme & 55 & $13 \%$ \\
\hline Karşılıklı güvenilir ilişkiler kurma & 49 & $11 \%$ \\
\hline İnsan kaynaklarının kökenine yatırım yapmak & 32 & $7 \%$ \\
\hline İnsan kaynaklarını sosyal sorumlulukla ele alma & 17 & $4 \%$ \\
\hline Toplam & $\mathbf{4 3 1}$ & $\mathbf{1 0 0 \%}$ \\
\hline
\end{tabular}

Buna göre, "yeteneği cezbetme ve çalışanların tercih ettiği bir şirket olma" ile "çalışanlar üzerindeki negatif etkilerin azaltılması" raporlamalarda en çok içerik paylaşılan, sürdürülebilirlikle ilgili insan kaynakları yönetimi kategorileridir. "Çalışanların yaşam standartlarını iyileştirme" kategorisindeki "sağlıklı bir yaşam tarzını teşvik etme" ve "iş ve iş dışı yaşam dengesini teşvik etme" başlıkları diğer kategoriler içerisinde de geçtiğinden herhangi bir uygulama örneği bu bölüm kapsamına alınmamıştır.

$\mathrm{Bu}$ kategoriler detaylı incelendiğinde şirketlerin raporlamalarında, yetene $\breve{~} i$ cezbetme ve çalışanların tercih ettiği şirket olmaya ilişkin şirketlerin sirasıyla en çok; "kültürel çeşitliliği ve cinsiyet eşitliğini sağlama", "sosyal olarak sorumlu ve güvenilir bir işveren olmanın yanı sıra, işyerinin itibarını aile dostu ve çalışan annelerin yanında bir şirket olarak güçlendirme" ve "iş tatmini ve motivasyon" konularındaki uygulamalara yer verdikleri görülmektedir. Çalışanlar üzerindeki negatif etkilerin azaltılmasına ilişkin ise "iş sağlığı ve güvenliği: iş kazaları, yaralanmalar ve ölümcül

Tablo 11

Insan kaynaklarinı sosyal sorumlulukla ele alma

Intranet platformu üzerinde İnsan Kaynakları - Çalışma Yaşamı altında Etik Kodu çalışanlarla paylaşılmakta

Kurumsal Sosyal Sorumluluk Etik Sözleşmesini imzalamış olma

Sosyal Uyumluluk Girişimi (Business Social Compliance Initiative BSCI) üyeliği

BM Ticaret ve İnsan Hakları Kılavuz İlkeleri'nin uygulamaya alınması

İnsan hakları eğitimleri

İş yerinde adalet: Operasyonlarda ve tüm tedarik zincirinde insan haklarının daha fazla

Etik ve çalışanlarla yakından desteklenmesi kararı

ilgilenme

Tüm beyaz yaka çalışanlar için İş Etiği Kuralları eğitimi

Herhangi bir pozisyon için 18 yaşın altındakiler işe alım süreçlerinde değerlendirmeye alınmaması ilkesi

Uluslararası Çalışma Örgütü standartları ile uyumluluk

Rüşvet ve Yolsuzluk ile Mücadele ve Etik İlke, Değer ve Davranış Kuralları gibi şirket politikalarını içeren konularda uzaktan eğitimler

Her çalışanın, başkalarının hak ve özgürlüklerine duyarlı olmak ve bu hak ve özgürlükleri tehdit etmemek şartıyla istek ve ihtiyaçlarını dile getirme hakkı

Kurumsal Sürdürülebilirlik konulu film yapımı

Çalışanlar göreve başlarken Etik Kuralları öğrenmekte, Kurumsal Etik Kurallar El Kitabı ve Kurumsal Etik Prosedürleri hakkında bilgilendirilmekte 
kazalar riskini azaltma”ya yönelik uygulamalara neredeyse tüm kategoriyi içerecek şekilde ağırlıklı olarak yer verilmiştir.

Her bir kategorinin altında toplanan uygulamalar, tekrar eden uygulamalar özetlenip, ayrı başlıklar halinde alt kriter tablolarında listelenmiştir.

İnsan kaynaklarını sosyal sorumlulukla ele alma kategorisinin bir diğer alt kategorisi olan işini kaybedenleri destekleme başlığına uygun birörneğe ise araştırma kapsamındaki hiçbir şirkette rastlanmamıştır. Bu durum şirketlerin iş akdinin süresi dolduktan sonra çalışanlarla herhangi bir şekilde ilişki kurmadığı şeklinde yorumlanabilir.

Tablo 12

Çalışan să̆lı̆̆ını ve esenliğini destekleme

\begin{tabular}{|c|c|}
\hline \multirow{6}{*}{$\begin{array}{l}\text { Çalışanlarda } \\
\text { kendi sağlıklarıyla } \\
\text { ilgili farkındalık } \\
\text { yaratma }\end{array}$} & Kadın sağlığı, meme kanseri vb çeşitli bilgilendirme toplantı ve seminerleri \\
\hline & Sağlıklı yaşam eğitimleri organizasyonu ve sağlıklı günler bültenleri yayınlanması \\
\hline & Şirket içi iletişim platformlarının kadın sağlı̆̆ına yönelik \\
\hline & olarak kullanımı \\
\hline & Güncel sağlık konularında bilgilendirme \\
\hline & İşyeri stresi, sigara bırakma, kalp hastalıkları, emzirme vb. başlıklarda seminerler \\
\hline \multirow{16}{*}{$\begin{array}{l}\text { Çalışanların } \\
\text { ve ailelerinin } \\
\text { esenliğini } \\
\text { destekleme }\end{array}$} & Acil sağlık hizmetleri, tedavi edici hekimlik hizmetleri, \\
\hline & Koruyucu sağlık hizmetleri \\
\hline & Çalışan ailelerine yönelik sağlık ve güvenlik eğitimleri \\
\hline & Veri kaydı ve sağlık istatistiklerinin oluşturulması \\
\hline & Çocuklar için Spor Kulübü faaliyetlerine ücretsiz katılma olanağ 1 \\
\hline & $\begin{array}{l}\text { Çalışan çocukları için yüzme, basketbol, futbol yaz okulları açarak çocuklar için de } \\
\text { spor olanakları yaratılması }\end{array}$ \\
\hline & Çalışan çocuklarına iş sağlığı ve güvenliği eğitimi \\
\hline & Çalışanlar odağa konarak onların mutluluğu ve sağlığına yönelik çalışmalar yürütülmekte \\
\hline & Çalışanların emniyetinin yanında fiziki ve ruhsal sağlığı da güvence altına alınmakta \\
\hline & Çevre sağlığı ve denetimi, içme suyu su ve gıda sanitasyonu \\
\hline & Göz ve diş tarama, omurga duruş check-up yaptırılması \\
\hline & Grip aşısı uygulaması \\
\hline & İnsülin direnci taraması \\
\hline & $\begin{array}{l}\text { İşe ilk girişte sağlık merkezince kapsamlı bir kontrol; sonrasında periyodik } \\
\text { muayenelerin yaptırılması }\end{array}$ \\
\hline & Kronik hastalıkları bulunan çalışanların kontrolü \\
\hline & $\begin{array}{l}\text { İş kazası ve meslek hastalığı geçirenlerin iş uyumunun değerlendirilmesi ve poliklinik } \\
\text { hizmetleri }\end{array}$ \\
\hline \multirow{3}{*}{$\begin{array}{l}\text { Çalışma yaşamı } \\
\text { kalitesinin } \\
\text { iyileştirilmesi }\end{array}$} & OHSAS 18001 İş Sağlığı ve Güvenliği Yönetim \\
\hline & Sistemi standartlarına uygunluk \\
\hline & Ulaşım, beslenme, ofis ergonomisi ve yaşam kalitesi gibi süreçlerde iyileştirme \\
\hline \multirow{3}{*}{$\begin{array}{l}\text { İşgücünün formda } \\
\text { olmasını sağlama }\end{array}$} & Çalışanlara spor yapma, nefes teknikleri ve yoga, zumba eğitimi gibi olanaklar \\
\hline & $\begin{array}{l}\text { Çevre spor kulüpleri kurumsal yapılanmasında; her branşa üst düzey yönetimden } \\
\text { sponsorlar atanarak sponsorların sporcuların temel ihtiyaçlarının karşılanması sağlanmakta }\end{array}$ \\
\hline & Spor eğitmeni eşliğinde ofis egzersizleri \\
\hline
\end{tabular}

Çalışan sağlığı ve esenliğini destekleme kategorisinde en çok çalışanların ve ailelerinin esenliğini destekleme alt başlığında uygulama örneği görülürken bu kategoriyi çalışma yaşamı kalitesi ve sağlıklı bir yaşam tarzını teşvik etmenin izlediği görülmüştür. En az yer verilen alt kategori olarak iş ve iş dışı yaşam dengesini 


\section{sağlamak için çalışmalara başlanmakla birlikte, henüz esnek çalışma modelleri} birçok şirket için yeni bir alan durumundadır.

Tablo 13

Calıșanlar üzerindeki negatif etkilerin azaltılması

SA8000 Sosyal Uygunluk Standardı

Çalışan temsilcilerinin de yer aldı̆̆ı İş Sağlı̆̆ı ve

Güvenliği Kurulları

Çalışanlara iş güvenliği uzmanları ve işyeri hekimleri tarafindan eğitimler verilmekte

(İSG) Denetçileri İçin Sertifikasyon Uygulaması

Dikkat ve Algı Testi (Viyana Test) yardımıyla iş makinesi operatörlerinin, bakım personelinin, kalite kontrol personelinin ve test şoförlerinin dikkat, alg1, konsantrasyon ve motor becerilerinin ölçülmesi

Çalışanlar ve yönetimin birlikte temsil edildiği İş Sağlığı ve Güvenliği Komiteleri

Hurdaların çevre ve işçi güvenliği açısından risk yaratmadan geri kazanılması

için titiz ve sistemli bir kontrol sistemi

ISG kurul, komite ve alt komite toplantıları, haberli ve habersiz güvenlik turları,

kazaya ramak kala uygulamaları, kaza kök neden analizleri

İSG risklerinin tespit edilip önlenmesine yönelik olarak

günlük, haftalık, aylık ve yıllık kontrol ve denetim çalışmaları

İş Güvenliği Simülasyon Eğitim Alanı (DOJO)

Drama yoluyla İSG eğitimleri verilmesi

İş Sağlığı ve Güvenliği (ISG) konusunda gerçekleşen tüm çalışmaların internet sitesi üzerinden paydaşlarına iletilmesi

İş sağlığı ve güvenliği: iş

Kuleli sahalarda güvenli çalışma ortamının yaratılmasına

kazaları, yaralanmalar

ve ölümcül kazalar

katkıda bulunmak üzere dikey yaşam hatları oluşturulması

Lojistik operasyonlar için güvenlik şartlarının üst düzeyde tutulması.

riskini azaltma

Ramak kala hadiseleri dahil tüm olaylar raporlanmakta; bu olayların kök neden ana-

lizleri incelendikten sonra, gerekli düzeltici ve önleyici faaliyetler uygulanmakta

Sağlık ve güvenlik verileri, online raporlama sistemleri vasıtasılla sistematik

olarak toplanarak, takip edilmekte ve incelenmekte

Saha koşullarına ve işin niteliğine göre kişisel koruyucu donanım temin edilmesi

ve bu donanımın kullanılması konusunda eğitimler düzenlenmesi

Şirket çalışanlarının yanı sıra müteahhit çalışanlarına yönelik olarak iş sağlığı ve güvenliği eğitimleri düzenlenmesi

Tedarikçi, bayi ve yetkili servislerin denetimi kapsamında İSG uygulamalarının değerlendirilmesi ve iyileştirme planlarının belirlenmesi

Tesis skor kartları ve ana faaliyet planı gözden geçirme toplantıları, vaka yönetim toplantıları, iş yeri hekimi ve sağlık personeli atölye ve sosyal alan sağlık turları düzenlenmesi

Tesise girecek olan herhangi bir paydaşın güvenlik eğitiminden geçirilmesi zorunluluğu

Üretim tesislerinin yanı sıra ofis ve yol emniyetini de kapsayan emniyet kuralları

kapsamında oluşturulan emniyet kılavuzları

Stajyer öğrencilere ve personele ilkyardım eğitimi verilmesi

İş Sağlığı ve Güvenliği konusunda personelin ilgisini çekmek ve bilinçlendirmek amacı ile her yıl "Slogan Yarışması" düzenlenmesi

Çalışanlar arasında iş sağlığ 1 ve güvenliği kültürünün artırılmasını/tanıtılmasını amacıyla "İş Sağlığı ve Güvenliği Tiyatro Gösterisi"

Her yıl planlı yangın, deprem ve bina boșaltma tatbikatları gerçekleşmesi

Ofis ergonomisi uygulamaları: Aydınlatma ve iç mekan hava kalitesini artırmaya, gürültü, nem ve sıcaklığı en uygun düzeye çekmeye ve kullanılan ekipmanları

Meslek hastalıkları iyileştirmeye yönelik çalışmalar.

riskini azaltmak için ergonomik çalışma Ergonomi ve endüstriyel hijyen çalışmaları koşullarını iyileştirme

Mesleki Hastalıklar ve Korunma yolları konusunda Şirket doktoru tarafindan bilgilendirme yapılmakta

Gerekli görülen alanlarda ortam ölçümleri (toz, gaz, gürültü, termal konfor, aydınlatma vb.) yapılarak, uygun olmayan çalışma ortamları standartlara uygun hale getirilmesi İcme sularının her ay düzenli olarak analizi

Stresi önleme ve azaltma psikoterapiler

Psikososyal birim ile stres faktörlerinin tespiti, iyileştirilmesi,bireysel ve grup

Psikososyal birim tarafından mavi yaka kadın çalıșanlara özel eğitim 
Çalışanlar üzerindeki negatif etkilerin azaltılması kategorisinde en fazla uygulama örneğine sahip alan olarak iş sağlığı ve güvenliği: iş kazaları, yaralanmalar ve ölümcül kazalar riskini azaltma alt kategorisi dikkat çekmektedir.

Diğer taraftan meslek hastalıkları riskini azaltmak için ergonomik çalışma koşullarını iyileştirme konusunda yapılanlar oldukça sınırlı düzeydedir. $\mathrm{Bu}$ durum şirketlerin sadece kazaları önlemeye yönelik faaliyetlere ağırlık verdiğini fakat etkisi daha uzun sürede gözlemlenebilecek meslek hastalıklarının oluşumunun önüne geçmek için koşulları iyileştirme konusunda yeterince aksiyon almadıklarını düşündürmektedir. Stresi önleme ve azaltma konusunda ise sadece iki uygulamanın bulunması konunun sembolik düzeyde farkına varıldığını ve bu durumun şirketlerin gündemine henüz girmediğini göstermektedir.

Tablo 14

Çalışanların yaşam standartlarını iyileştirme

\begin{tabular}{|c|c|}
\hline \multirow{5}{*}{$\begin{array}{l}\text { İş ve iş } \\
\text { dışı yaşam } \\
\text { dengesini teşvik } \\
\text { etme }\end{array}$} & $\begin{array}{l}\text { "Mobil Çalışma", "Günü Planla", "Part-time çalışma" ve "Ofistasyon” isimleriyle farklı } \\
\text { yerlerdeki ofislerden çalışma esnekliği ile çalışanlara işlerini daha etkin ve verimli yönet- } \\
\text { me imkânı sunulması }\end{array}$ \\
\hline & Esnek çalışma modellerine geçilmesi hedeflenmekte \\
\hline & Çalışanlar tiyatro ve konserler için kolayca bilet bulabilmekte \\
\hline & $\begin{array}{l}\text { Mesai saatinin } 7.30 \text { 'da - } 16.35 \text { arası olması; çalışanların sabah ve akşam yoğun trafiğini } \\
\text { yaşamalarının önüne geçilmesi }\end{array}$ \\
\hline & $\begin{array}{l}\text { Çalışanların esnek mesai yaparak çalışma saatlerini günlük zorunlulukları çerçevesinde } \\
\text { planlamalarına olanak sağlanması }\end{array}$ \\
\hline \multirow{3}{*}{$\begin{array}{l}\text { Sağlıklı bir } \\
\text { yaşam tarzını } \\
\text { teşvik etme }\end{array}$} & Beslenme danışmanlığı ve diyetisyen hizmeti \\
\hline & Sağlıklı beslenme, madde bağımlığı bilinci ve dumansız ortam gibi uygulamalara destek \\
\hline & Sağlıklı yaşam konusunda yol gösterici yenilenme programı gibi olanaklar sağlanması \\
\hline
\end{tabular}

Yetenek yönetimine ilişkin konu ve uygulamalar, yukarıda değinildiği gibi içeriğin en geniş olduğu konulardan biridir ve Tablo 15 'de sunulmaktadır:

Tablo 15

Yeteneği cezbetme ve "çallşanların tercih ettiği bir şirket” olarak tanınma

"Best Employer - Türkiye'nin En İyi İşyeri” unvanı

Çalışanların performans hedefleri arasında sürdürülebilirlik yönetimine ilişkin konular da yer almakta

Cazip ve aynı

zamanda zorlayıcı bir iş ortamı Flex Performans Sistemi ile daha esnek, birimlerin ihtiyacına uygun bir performans sistemi Genç yetenekleri çekmek için yenilikçi işe alma süreci

sunmak Görüşme Deneyim Anketi ile işe alım süreçlerine katılan adayların görüşme sürecinde yaşadıkları deneyim üzerinden bilgi paylaşmaları istenmekte

Belirlenen hedef üniversitelerin potansiyeli yüksek öğrencilerinin çalışma hayatını tanımalarını ve iş olanaklarından haberdar olmalarını sağlayan, program sonunda işe alımların yapılacağı üç günlük yetenek kampı 
Tablo 15

Yeteneği cezbetme ve "çalışanların tercih ettiği bir şirket" olarak tanınma

Çalışanlara kişisel, mesleki ve teknik bilgi ve becerilerini artırma olanakları sunarak bir yandan bireysel başarı ve motivasyonu artırırken diğer yanda da organizasyonel gelişimi sağlamayı hedefliyor

Eğitimin Büyük Çark1 "Big Wheel of Training" ile eğitimcilerin bir araya gelmesi, birbirleriyle etkileşim içinde olması ve sürdürülebilirliğin sağlanması

Çalışanlara ve onların yetenekleriyle bilgilerine yatırım yapma

Gerek sınıf içi eğitimler, gerekse mentorluk ve deneyime dayalı öğrenme gibi uygulamalar ile çalışanların potansiyellerini keşfederek ortaya çıkarmaları adına gelişim faaliyetleri Öğrenme ve gelişim faaliyetlerinin iş sonuçlarında yarattığ raporlanması ile sürekli iyileştirilen bir öğrenme ve gelişim sistemi

Yeni yöneticiler için mentorluk sisteminin yanında finans, hukuk ve insan kaynakları sistemlerini öğrendikleri sınıf içi ve uzaktan öğrenme programları

Her bir çalışanın sahip olduğu yetkinlikler ve iş tanımı gereği sahip olması gereken yetkinlikler arasındaki fark analiz edilmekte; analiz sonucunda elde edilen yetkinlik ihtiyaçları kullanılarak öğrenme ve gelişim ihtiyaçları belirlenmekte ve bu ihtiyaçları karşılayacak ögrenme ve gelişim programları hazırlanmakta

Çalışanlara gelişen teknolojiler ve yeni iş alanları ile ilgili bilgi ve becerileri proaktif bir planlama sonucunda kazandirmakta

Runtalya ve İstanbul Maratonu etkinliklerine katılım

Buluş sahibi çalışanlar ödüllendirilmekte

Çalışan Memnuniyet Anketi

Çalışanların hayatını kolaylaştırmak ve mutluluğunu artırmak için ek doğum günü izni, anlaşmalı şirketlerle kampanyalardan yararlanma hakkı

Farklı kategorilerde ödüllendirme programları

Fotoğrafçılık kursu, koro çalışmaları, tiyatro, yelken ve dalış gibi birçok sosyal kulüp aktiviteleri

İs tatmini ve motivasyon

Geziler, tiyatro ve spor faaliyetleri

Happy hour etkinlikleri (Oktoberfest, Bağ bozumu gibi)

"İşte Buna Ödül Verilir" diyerek yenilikçi ve fark yaratan çalışmaların ödüllendirilmesi

Kuru temizleme hizmeti

Kütüphane açılışı

Sosyal kulüpler bünyesinde, konser, sergi, gösteri ve konferans ve sportif etkinlikler

Ücretsiz veya indirimli iç/dış hat seyahat olanakları, vize işlemlerinde kolaylıklar, anlaşmalı otellerde konaklama imkanı vb.

Yedi yıl ve üzerinde çalışanlara "Yenilenme İzni” kullanma hakkı sunuluyor

Fotoğrafçılık Kulübü, Türk Halk Dansları Kulübü, Doğa Sporları Kulübü

Çalışanlar oluşturulan kariyer haritalarına, şirket içindeki açık pozisyonlara ve kariyer fursatlarına dair bilgilere “İntranet Portalı'ndan” erişebilmekte

Genç istihdamı desteklemek amacıyla mühendislik bölümleri başta olmak üzere, yeni mezun işe alım programı

İç ilan sistemi ile boş pozisyonlar tüm çalışanlara ilan edilerek farklı fonksiyon ve

Kariyer lokasyonlarda çalışma teşvik ediliyor. 
Tablo 15

Yeteneği cezbetme ve "çalışanların tercih ettiği bir şirket" olarak tanınma

Ayrımcılık karşıtı, adil, huzurlu, gelişim odaklı ve insana değer verilen bir iş ortamı

Çalışan herkese işe girişten itibaren cinsiyetinden bağımsız olarak eşit firsatlar yaratma çabası

Çeşitlilik kurum kültürünün bir parçası

Çocuk ve zorla işçi çalıştırma ile ilgili olarak önemli risk taşıyabilen operasyon bulunmaması

HeForShe hareketine destek

İstihdamda pozitif ayrımcılık politikası doğrultusunda ofis çalışanı işe alımlarında her 2

kişiden 1 'inin, saha çalışanı işe alımlarında ise her 4 kişiden 1'inin kadın olması ilkesi

İş’te Eşitlik projesi kapsamında kadın çalışanlara eğitimler, koçluk ve mentorluk desteği

İşgücündeki farklılıkların bir zenginlik olarak görülmesi ve çeşitliliğin desteklenmesi

Kadın çalışanlara yasal hakların çok üzerinde, uzatılmış izin hakları

Kadın çalışanların yetkinliklerinin geliştirilmesine öncelik vererek kadınların üst yönetim düzeyinde görev almalarının önünü açacak çalışmalar yürütülmekte

Kadın yönetici oranını artırma hedefi

Kültürel (Kadınlar için) Değer zinciri boyunca sunulan firsatları genişletme

çeșitliliği

ve cinsiyet

eşitliğini

(Kadınlar için): Eğitim ve becerilere erişimi artırma

Faaliyet gösterilen toplumlarda kadın güvenliğini destekleme

sağlama

Yönetime odaklanarak cinsiyet açısından dengeli bir organizasyon inşa etmek

Kadının Güçlenmesi Prensipleri (WEPs) imzalama

KAGIDER'in Dünya Bankası desteği ile verdiği "Fırsat Eşitliği Sertifikası"

Yönetim Kurulu Üyesi seçimi yapılırken bilgi, deneyim ve yetkinlik açısından aynı özelliklere sahip adaylar içerisinden kadın üye seçimine öncelik verilir” ilkesi

Uluslararası proje ortaklıklarında görevlendirilen çalışanlar farklı ülkelerden araştırmacıların yer aldığı gruplarda ileri teknoloji ürünlerinin geliştirilmesine katkıda bulunmakta

Artan Y kuşağına yönelik, takdir ve ödül bazlı uygulamalar geliştirilmesinin yanı sıra her kuşağa en iyi şekilde uyacak yaklaşımların iyileştirilmesi

Engelli vatandaşlar için istihdam olanağı yaratmak ve engelli çalışanların şirket bünyesinde çalışma koşullarını mümkün olan en iyi seviyeye ulaştırmak için her türlü kaynak kullanılmakta

Kadının ekonomik yaşamın her alanına eşit katılımı amacıyla tedarikçiler, müşteriler, ajanslar ve paydaşlarla bir araya gelerek; Kadının Güçlenmesi platformu

'Dünya Ekonomik Forumu Cinsiyet Eşitliği Uçurumunun Kapatılması Programı' kapsamında oluşturulan 'İş’te Eşitlik Platformu

Anne - Bebek Politikası oluşturma

Anneler için esnek çalışma koşulları

Anneler için okulun ilk gün izni

Sosyal olarak

sorumlu ve

güvenilir

bir işveren

olmanın yanı

sıra, işyerinin

itibarını

aile dostu

ve çalışan

annelerin

yanında bir

şirket olarak

güçlendirme
(Çalışan aileleri için) Kültürel geziler, Piknik ve sosyal organizasyonlar

Çalışan çocuklarına burs desteği

Çalışanlar çocuklarını evdeki kamera sistemleriyle işyerinden istedikleri zaman kontrol edebilmekte

Çalışanların iş arkadaşları ve yöneticileriyle iletişimlerini güçlendirmek amacıyla iş

dışında sosyalleşmelerini

sağlayacak etkinlikler düzenleniyor.

Fabrikadaki sosyal tesisleri tüm çalışanlar, eşleri ve çocuklarıyla birlikte kullanabilmekte

Kreş yardımı uygulaması ile 0-72 ay arası çocuk sahibi kadın çalışanlar ile bu yaş aralığındaki çocuğuna tek başına bakmakla yükümlü erkek çalışanlara kreş yardımı

Süt odası hizmeti, hamile sağlık hizmetleri

Yeni doğum yapan kadınların, çalışma hayatına daha çabuk adapte olmaları ve iş-yaşam dengelerini koruyabilmeleri için esnek çalıșma imkanı

Babalık izni

Türk Halk Müziği ve Türk Sanat Müziği Korolarının verdiği ücretsiz yıllık konserlerde çalışanlar ve aileleri bir araya gelme imkânı 
Tablo 15

Yeteneği cezbetme ve "çalışanların tercih ettiği bir şirket" olarak tanınma

Bireysel Emeklilik Uygulaması ile kıdeme göre çalışanların brüt maaşının \%2'si ila \%3'ü oranında katkı payı ödemesi

İstirahatli çalışana ücret ve özel sağlık kuruluşlarında tedavi giderlerinin karşılanması, yılda bir kez faizsiz kredi uygulaması, avans çekme hakkı, işçi servisleri, sağlık merkezi, lojman ve kaza sigortası

Çalışanların farklılaşan ihtiyaçlarına esnek çözümlerle cevap vermeyi hedefleyen bir yan fayda modeli

Doğum, emzirme, vefat ve evlilik izin ve ödenekleri,

Ücretlendirme

Esnek ek menfaat programı: Flex Menu alışveriş çeklerinden tatil paketine, bireysel emek-

ve ek sosyal

olanaklar

lilik ara ödemesinden sağlıklı yaşam paketi

Eşit işe eşit ücret ilkesi doğrultusunda adil ücretlendirme uygulamaları

Özel sağlık sigortası ve çalışan ailelerine özel sağlık sigortası indirimleri

Performans çıktıları üzerinden ücret ve prim sistemi

Sosyal Güvenlik Kurumu tarafından en yüksek SGK primi ödeyen ve prim borcu olmayan kuruluş olarak ödüllendirilme

Tam zamanlı çalışanlara sağlanan maaş dışındaki yardımlar; yakacak, evlenme, doğum, ölüm, askerlik, çocuk, öğrenim, yemek, vasıta, ayakkabı, doğal afet, erzak, temizlik malzemesi yardımları, ikramiye, bayram ve yıllık ücretli izin harçlığı

Tüm ofis çalışanları işe girişte Emekli ve Yardım Sandığı Vakfı'na üye olmakta

Ücretlerin her yıl çalışanın performansına göre artırımı

Şirketlerin gerek Kadının Güçlendirilmesi İlkeleri, gerekse İş’te Eşitlik Platformu aracılığıyla cinsiyet eşitliğini sağlama konusunda öncü adımlar attığı gözlemlenmiştir.

Tüm şirketlerin raporlarında çalışan gelişimine geniş yer ayrılmış, çalışanların karar süreçlerine etkin katılımı, şirket faaliyetlerinden haberdar olmalarını sağlamak amacıyla birçok iletişim ara yüzünün kullanıldığı belirlenmiştir. Bu uygulamalar Tablo 16'da gösterilmektedir.

Tablo 16

Mevcut iş gücünün becerilerine yatırım yapma

"Çevresel farkındalık" uzaktan eğitimi

Dijital akademi

Harvard Üniversitesi uzaktan eğitim programlarıyla bütünleştirilen eğitim konseptiyle Liderlik Okulu

Hedeflerin yanı sıra yetkinlik bazlı değerlendirilen çalışan gelişiminin, değerlendirme sonunda atanan eğitimler ile desteklenmesi

Çalışan gelişimi ve eğitim programları
Her kademedeki çalışana, liderlik, yetkinlik ve yetenek geliştirme programları, özel eğitim programları ve yabancı dil, işe giriş eğitimi ve hizmet içi eğitim programları düzenlenmesi

İşe yeni başlayan çalışanlara video eğitim, "iş başı

koçluk" çözümleri ve sınıf içi vaka uygulamalarını içeren İşe Başlangıç Programları

Yeni Mezun Gelișim Programı ile ișe alınan yeni mezun çalıșanların gelișimlerinin takibi.

Uçuş Eğitim Merkezi

Yakıt verimliliği ile ilgili alanlarda çalıșanlara eğitim verilerek çevre bilinçlerinin artırılması hedefleniyor 
Tablo 16

Mevcut iş gücünün becerilerine yatırım yapma

360 Derece Yetkinlik Değerlendirme yaklaşımı ile çalışanlar, yöneticilerine ve iş arkadaşlarına Liderlik Prensipleri ile ilgili geri bildirim verme imkanı

Çalışanlarının kendi kariyer gelişimlerinde proaktif şekilde rol almaları için desteklenmesi

Çalışanlar ve yöneticiler için kariyer gelişimi
Deneyimli yöneticilerin birebir koçluk görüşmelerini de içeren proje çalışmalarına katılımı İnsan Kaynakları Planlama süreci ile her yıl tüm çalışanların kariyer gelişimi gözden geçirilmekte

Mavi yaka için de farklı kariyer alternatifleri

Rotasyon uygulamalarıyla çalışanlara farklı alanlarda yöneticilik ve uzmanlık tecrübesi kazandırma

Mentorluk sistemi ile şirket içi birbirinden öğrenme ve liderlik gelişimi destekleniyor

Mentorluk Koçluk, mentorluk, rotasyon gibi farklı öğrenme teknikleri, e-öğrenme gibi farklı eğitim teknolojilerinin kullanımı

Çalışanların gelişimini destekleyecek konferans, seminer ve webinar gibi gelişim aktiviteleri Çalışanların kişisel gelişimlerini destekleyici atölye programları, konuk konuşmacı programları ve iç eğitimler

Çok gelişmiş bir kütüphanenin varlı̆g 1

Yaşam boyu

TÜBİTAK anlatımıyla Araştırma Destek Programları Bilgi Günü

öğrenmeyi

destekleme

Tüm çalışanlar için görev tanımları ile uyumlu alanlarda yapacakları yüksek lisans ve doktora eğitimi kapsamında kullanılabilecek ücretli okul izin olanağı

Stratejik önemi olan alanlarla ilgilenen öğrencileri ve çalışanları destekleyerek, yeni teknolojilere yönelik bilgi seviyesini artırmak üzere uzun vadede insan gücünü geliştirmek için personel yurt dışında yüksek lisans, doktora, bütünleşik doktora ve araştırma programları için desteklenmekte

\begin{tabular}{ll}
\hline $\begin{array}{l}\text { Yedekleme planı, } \\
\text { yetenek havuzları }\end{array}$ & $\begin{array}{l}\text { Grup içindeki yönetim pozisyonları için "Yetenek Yönetimi” süreci ile yedekleme planları } \\
\text { Kısa ve uzun vadeli yedekleme planları hazırlanmakta }\end{array}$ \\
\hline $\begin{array}{l}\text { Çalışanların iş sonuçları ve yetkinlikleri baz alınarak yürütülen performans değerlendirme } \\
\text { Yetenek yönetimi } \\
\text { ve kariyer yönetimi } \\
\text { programları }\end{array}$ & $\begin{array}{l}\text { sistemi sonuçları bireysel kariyer yönetimi ve yetenek yönetimi süreçlerinin temelini } \\
\text { oüm çalışanlar yetenek olarak tanımlanarak çalışanların farklı konularda sahip oldu- } \\
\text { ğu yeteneklerin tespit edilmesi ve bu yetenekleri geliştirmelerine olanak sağlayacak } \\
\text { imkanlar yaratılması }\end{array}$ \\
\hline
\end{tabular}

Mevcut işgücünün becerilerine yatırım yapma kategorisinde şirketlerin çalışanları için çok çeşitli eğitim ve kariyer gelişim programları tasarladıkları, bu eğitim programlarının sektör ve çalışma alanlarına göre de farklılık gösterdiği gözlemlenmiştir. İnsan kaynağının sürdürülebilirliğini sağlama ve bilgi birikiminin şirkette kalması için de yedekleme planları aktif olarak kullanılmaktadır. Bu kategoride koçluk ve mentorluk uygulamalarının henüz az şirket tarafından benimsendiği, kurum içi öğrenme ve işbirliğine vurgu yapılırken bu alanın henüz sistematik bir seviyeye gelmediği de bulgular arasındadır. 
Tablo 17

İnsan kaynaklarınin özüne yatırım yapma

Okul ve yurt inşaat ve altyapı destekleri, öğrenci bursları, meslek edindirme ve benzeri projelere yatırım

Bölgedeki üniversite, yüksekokul, lise ve ilköğretim öğrencilerinin tesislerde inceleme ziyareti Meslek lisesi öğrencilerine beceri eğitimi, meslek yüksekokul ve üniversite öğrencilerine yaz stajı ve mezun durumundaki mühendis/uzman öğrencilere (intern) staj imkanı

Öğrenciler, potansiyel çalışanlar, stajyerlere fabrika tanıtım gezileri ve çevre, İSG vb.

Eğitime, staja konularda sunumlar

yatırım yapma Öğrencilere burs imkanı

Tedarikçi ve bayilere yönelik eğitimler

UMEM projesi kapsamında Mesleki ve Teknik Liselerde kaynak, sapancilık, tornacılık ve çelik üreticiliği vb başlıklarda kursların düzenlenmesi

Her yıl Haziran-Eylül ayları arasında, 850 ila 950 yükseköğretim öğrencisi yaz stajı yapmakta; staj süresince bölümler öğrencileri gözlemlemekte ve onları gelecekteki olası çalışanlar olarak değerlendirmekte

Meslek Yüksek Okulu'nda eğitimler verilmekte

Boğaziçi Üniversitesi Otomotiv Yüksek Lisans Programı ve Koç Üniversitesi ile geliştirilen Tech MBA ve Executive MBA programları

Havacılık Akademisi kapsamında Fatih Sultan Mehmet Üniversitesi'nde Liderlik Gelişim Programı

Işık Üniversitesi ile birlikte mavi yaka için modüler bir gelişim programı

Koç Üniversitesi işbirliği ile TECH PRO Akademi ile mühendislerin uzmanlık kariyerinin desteklenmesi

MIT işbirliğinde inovatif liderlik programı

Üniversitelerle işbirliği

Müdür ve șef olarak görev yapan mesleklerinde başarılı 12 kișilik bir grup mühendisin ÇOMÜ de 11 farklı meslek dersi yürütmesi

Üniversitelerin kariyer etkinliklerine katılım

Uludağ Üniversitesi ile ortak yürütülen Otomotiv Yüksek Lisans Programı

Üniversite işbirlikleri ile çalışanlara yüksek lisans ve sertifika programları başvurularında indirim avantajları

Tüm yönetici kademeleri Harvard Business School'un uzaktan öğrenme aracı Harvard Manage Mentor ve dünyanın en büyük online kütüphanesi olan GetAbstract'tan yararlanabimesi

Çalışanların ulusal/ uluslararası konferans, kongre ve

zirvelere katılımlarının sağlanması ve Konferansta sözlü bildiri sunumu

Üniversiteler, araștırma ve devlet kurulușları ile ilgili firmaların katılımı ile 3 Çalıștay, 1 Sempozyum ve Bilgi Günü katılımı

Sürdürülebilirlik raporlarının incelenmesi sonucu şirketler tarafından üniversitesanayi işbirliğinin öneminin kavrandığı görülmüştür. Şirketler, birçok üniversite ile işbirliğinde bulunarak gerek kayıt avantajları gerekse kariyer etkinliklerine katılım sağlayarak çalışan ve potansiyel çalışanları geliştirmeyi hedeflemektedir.

Karşı1ıklı güvenilir ilişkiler kurma kategorisi altında sadece çalışanların güvenini kazanma ve sürdürülebilir ilişkileri yaratma alt başlığı yer almış, bu alt kategoriye ilişkin uygulama örnekler Tablo 18'de listelenmiştir. 
Tablo 18

Karşılıklı güvenilir ilişkiler kurma kategorisi uygulama örnekleri

Tüm çalışanların katılımıyla düzenlenen toplantılarda değişen İnsan Kaynakları uygulamaları hakkında bilgiler verilmekte

Sürdürülebilirlik anketi ile çalışanlar sürdürülebilirlik performansını değerlendirmesi Açık kapı toplantıları, liderlik toplantıları, intranet portalı, Genel Müdür mesaj bülteni, şirket dergisi, şirket TV, SMS ve kitlesel e-posta iletişimi

Aday Öneri Sistemi sayesinde çalışanların yetenek kazanımı süreçlerine katılımı Çalışan Deneyimi Yönetimi uygulaması

Çalıșana terfi mektubuyla kişiye özel bilgilendirme ve portal üzerinden genel bir bilgilendirme yapılmakta

Personelin seçimle kendi temsilcisini belirlediği bir "Personel Temsilciliği"

Çalışanların fikirlerini iletebileceği bir "Bireysel Öneri Sistemi" platformu

Calıșanların kurallara ve prosedürlere her an ulaşabilmeleri için șirket içi iletișim sayfası

Çalışanların

Güvenini

Kazanma ve

Sürdürülebilir

İlişkileri

Yaratma

olan "İSG Portal” üzerinden İSG Politikası, yasal mevzuat ve prosedürler paylaşılıyor

"Açık Kapı İK" toplantılarıyla insan kaynakları süreçleri çalışanların görüşlerini alarak yapılandirılması

Genel Müdür'ün çalışan gruplarıyla öğle yemeğinde bir araya gelmesi, onların sorunlarını ve önerilerini dinleyip Şirket hakkındaki bazı bilgileri paylaşması

İntranet sistemine ek olarak kurum içi sosyal ağ uygulamaları

Orta kademe yöneticilere yönelik yönetim bilgilendirme toplantıları

Tüm çalışanları ilgilendiren konuların (çalışan hakları, sigortalar, izin durumları, iş kanununda meydana gelen değişiklikler, organizasyonel değişiklikler vb.) çalışanlara toplu olarak e-posta yoluyla bilgilendirme

15-20-25-30 ve 35 yılını doldurmuș çalışanlar için Hizmet Ödül Törenleri

İş sağlığ1 ve güvenliği konularına ilişkin işveren yükümlülükleri toplu iş sözleşmesi kapsamında güvence altına alınmakta

Örgütlenme özgürlüğüne ve toplu sözleşme haklarına saygı, çalışanları ve sendikalar ile kurduğu güven ilişkisi ile işyeri barışını korumayı temel prensibi olarak benimsemekte

Sendika temsilcilerinin ve işçi temsilcilerinin de katıldığı aylık değerlendirme toplantıları

Tedarikçi ve iş ortaklarından sendikal hakların eksiksiz uygulanması talebi

Toplu iș sözleşmelerinde daha iyi çalıșma koşulları, iș sağlığı ve güvenliği, doğum, vefat, eğitim ve evlilik desteği gibi konulara yer verilmekte

Çalışmamız Ehnert (2009)'in şirketlerin sürdürülebilirliği ve sürdürülebilir gelişmeyi nasıl tanımladığını ve bunu insan kaynaklarının yönetimi ile nasıl ilişkilendirdiklerini incelediği çalışmasında yer alan 8 ana başlık çerçevesinde hazırlanmıștır. Ancak Türkiye'deki uygulama içeriğinin dağılımına ve temalarına bakıldığında konunun farklı başlıklar altında incelenmesi önerilmektedir. Öncelikle, original çalışmada da aynı anda iki başlık altında olan, iş ve iş dışı yaşam dengesinin teşvik etme, sağlıklı bir yaşam tarzını teşvik etme maddeleri içerik konularına gore yalnızca "Çalışanların yaşam standartlarını iyileştirme" kriterinde bırakılmıştır. Yine, "Mevcut çalışanların becerilerine yatırım yapma" kriterindeki kariyer olanakları sunma ile "Yeteneği cezbetme ve çalışanların tercih ettiği bir şirket olarak tanınma" kriterinde olan yetenek yönetimi ve kariyer yönetimi programları maddeleriyle ilgili içerikler birbirine çok yakın olduğundan birbirinden ayrılarak sadeleştirilmesi gerekmiştir. Ayrıca, Türkiye’ye özgü olarak aile uygulamalarının sıklığı bu konunun 
ayrı bir madde olarak ele alınması gerektiğini düşündüştür. Buna göre oluşturulan yeni kategoriler Tablo 19'da gösterilmektedir. Yeri değişen, ya da farklı bir şekilde ifade edilen kategoriler ĕgik yazı ile gösterilmiştir.

Tablo 19

Türkiye'deki sürdürülebilirlik uygulamaları ışı̆̆ında gözden geçirilmiş sürdürülebilirlik kategorileri ve ilgili insan kaynaklart uygulamaları

\begin{tabular}{ll}
\hline İnsan kaynaklarını sosyal sorumlulukla ele alma & Yeteneği cezbetme ve "çalışanların tercih ettiği bir \\
- Etik ve çalışanlarla yakından ilgilenme & şirket" olarak tanınma \\
- İşini kaybedenleri destekleme & Çalışanlara ve onların yetenekleriyle bilgilerine \\
& yatırım yapma \\
& - Kariyer olanakları sunma \\
& - Cazip ve aynı zamanda zorlayıcı bir iş ortamı sunma \\
& - Sosyal olarak sorumlu ve güvenilir bir işveren ola- \\
& rakişyerinin itibarını güçlendirme \\
& - Yetenek havuzu \\
& - Ücretlendirme ve ek sosyal olanaklar \\
\hline
\end{tabular}

Çalışan sağlığ ve esenliğini destekleme

- Çalışma yaşamının kalitesini iyileştirme

Mevcut çalışanların becerilerine yatırım yapma

- Çalışanlarda kendi sağlıklarıyla ilgili farkındalık • Çalışan gelişimi ve eğitim programları yaratma

- İşgücünün formda olmasını sağlama

- Mesleki eğitim programları ve çıraklık

- Çalışanların ve ailelerinin esenliğini destekleme

- Yedekleme planlarl

- Çalışanlar ve yöneticiler için kariyer gelişimi

- Mentorluk

Çalışanlar üzerindeki negatif etkilerin azaltılması İnsan Kaynaklarının özüne yatırım yapma

- İş sağlı̆̆ı ve güvenliği: iş kazaları, yaralanmalar - Eğitime, staja yatırım yapma ve ölümcül kazalar riskini azaltma

- Yaşam boyu öğrenmeyi güçlendirme

- Meslek hastalıkları riskini azaltma

- Üniversitelerle işbirliği

- Ergonomik çalışma koşullarını iyileştirme

- Stresi önleme ve azaltma

- İş sağlığı ve güvenliği eğitimleri

Çalışanların yaşam standartlarını iyileştirme

- Sağlıklı bir yaşam tarzını teşvik etme

- İş ve iş dişı yaşam dengesini teşvik etme

- Çalışan annelerin yanında bir şirket olma

Karşılıklı güvenilir ilişkiler kurma
- Çalışanların güvenini kazanma ve sürdürülebilir
ilişkiler yaratma
- Sosyal aktiviteler düzenleme
- İş tatmini ve motivasyon
- Aile dostu bir şirket olma

Tablodan da görüleceği gibi, "Çalışanlar üzerindeki negatif etkilerin azaltılması" boyutundaki maddelerin, içeriğin yoğunluğu ve dağılımı gözönünde bulundurularak yeniden yapılandırılması gerekmiştir. Buna göre bu kriterin içeriği üç yerine beş madde olmaktadır. Bir diğer önemli değişiklik, Türkiye'de 'karşılıklı güvenilir ilişkiler kurma" başlı̆̆ı altındaki içeriğin daha çok iletişim, sosyal aktiviteler ve aileyi içeren uygulamalarla örtüştüğü görüldüğünden bu kriter de yeniden tanımlanmıştır.

\section{Tartışma}

Çalışmamız tüm dünya için öncelikli bir konunun Türkiye'de nasıl ele alındığını iki ayrı kesit ve yaklaşım üzerinden açıklayarak sürdürülebilirlik çalışmalarına katkı yapmaktadır. İlk çalışmada, Türkiye'de işyerlerinde çevreyi korumaya dönük uygulamaların neler olduğu hakkında çalışanlardan bilgi alınmış, bunun 
yanında çalışanların çevreye ilişkin tutumları ve çevre yararına olan davranışları ile işyerlerindeki çevre dostu uygulamalar arasında bir ilişki olup olmadığı araştırılmıştır. Öte yandan çalışanların çevreye ilişkin tutum ve davranışlarının sektörler bazında farkl111k gösterip göstermediği de sorgulanmıştır. Elde edilen bulgulara göre, şirketlerin çevre dostu uygulamaları içinde geri dönüşüm uygulamalarının ağırlıklı bir yeri bulunmaktadır. Bu durum geri dönüşüm uygulamalarının, özellikle kağıt atıkların işyerlerinde geri dönüşüme kazandırılacak şekilde toplanmasının diğer uygulamalara göre daha kolay hayata geçirilmesi ve görünürlüğü ile açılanabilir. Ancak, katılımcıların yalnızca \% 1'nin "enerji tasarrufu" uygulamasından bahsetmiş olması konunun iklim değişikliği ile ilgisi düşünüldüğünde Türkiye'deki uygulamaların henüz emekleme aşamasında olduğunu göstermesi açısından düşündürücüdür.

Bu çalışmadan elde edilen diğer bir bulgu ise şirketlerin çevre dostu uygulamalarının varlı̆̆ ile çalışanların çevre dostu davranışları arasında istatistiksel olarak olumlu yönde ilişki bulunduğu yönündedir. Şirketlerin çevre dostu uygulamalarının varlığının, çalışanların çevreye yönelik aktivist davranışlarını artırması pratik karşıllı̆ı olan önemli bir bulgudur. Benzer bir çalışmada Rueper, Keizer ve Steg (2017) çalışanların çalıştıkları şirketlerde Şirket Çevre Sorumluluğu (Corporate Environmental Responsibility-CER) performansını olumlu algilamaları durumunda, çevreci değerler bakımından düşük seviyede olsalar bile çevre yanlısı davranışları gösterdiklerini rapor etmektedir. Araştırmacılar, insanların durumsal faktörlerin etkisi ile iş yerlerinde çevreci davranışlar gösterebildiklerini aktarmakta, şirketlerin çevre politikalarını hayata geçirdiklerinde çalışanların davranışlarının da olumlu yönde geliştiğini ve ilgili yöneticilerin bu durumun farkında olmalarını vurgulamaktadırlar.

Çalışanların yeşil tutum ve davranışlarında, çalıştıkları sektörlere göre bir farklılık olup olmadığını anlamak için yapılan analizlerde elde edilen sonuçlara göre; çevreye yönelik korumacı tutuma sahip olma ve çevreyi koruma davranışları bakımından özel sektör çalışanları ile endüstri işkollarında çalışanlar, kamu sektöründe ve diğer işkollarında çalışanlara göre daha az çevre yanlısı tutum ve davranış sergilemektedir. Aynı zamanda, çalışanların beyan ettikleri çevre konusundaki eğitim, gezi ve proje uygulamalarının toplamda \%3'ü geçmediği görülmektedir. Bu bağlamda, işletmelerin çevre üzerindeki olumsuz etkilerini doğrudan azaltan; "işin yapılış şeklini çevreye karşı daha duyarlı / sorumlu seçeneklerle değiştirme ve sürdürülebilir ürün ve işlemler yaratma"ya (Ones ve Dilchert, 2012) yönelik çalışmaların yeterli olmadığı, gidilecek daha çok yolumuzun olduğu söylenebilir.

İkinci çalışmada, Türkiye'de sürdürülebilirlik uygulamalarında öncü şirketlerde insan kaynaklarının sürdürülebilirliğine ilişkin neler yapıldığı araştırılmış ve insan kaynakları yönetimi fonksiyonları ile sürdürülebilirlik arasındaki ilişki sorgulanmıştır. Çalışmada, hepsi farklı sektörlerde faaliyet gösteren, 9 özel sektör 
işletmesinin 2016 yılına ait sürdürülebilirlik raporlarındaki insan kaynakları ile ilgili bölümler içerik analizi tekniği ile ele alınmış ve "IKKY ile ilişkili sürdürülebilirlik faaliyetleri” kod listesi oluşturularak değerlendirilmiştir. Bu kodlar Ehnert (2009) tarafindan oluşturulan "IKY ile ilişkili sürdürülebilirlik kategorileri" (Tablo 1) kod listesi altında gruplanarak değerlendirilmiştir. Ehnert (2009)'in şirketlerin sürdürülebilirliği ve sürdürülebilir gelişmeyi tanımlayarak insan kaynakları yönetimi ile ilişkilendirdiği faaliyetler sekiz temel başlıkta toplamaktadır: a) İnsan kaynaklarını sosyal sorumlulukla ele alma, b) çalışan sağl $\breve{g ̆}_{1}$ ve esenliğini destekleme, c) çalışanlar üzerindeki negatif etkilerin azaltılması, d) yeteneği cezbetme ve "çalışanların tercih ettiği bir şirket" olarak tanınma, e) mevcut çalışanların becerilerine yatırım yapma, f) insan kaynaklarının kökenine yatırım yapma, g) çalışanların yaşam standartlarını iyileştirme, h) karşıllklı güvenilir ilişkiler kurma.

$\mathrm{Bu}$ temel başlıklar altında gruplanan faaliyetlere bakıldığında en çok göze çarpan bulgu, şirketlerin sürdürülebilirlik raporlarında, çalışanların yetenekleriyle bilgilerine yatırım yapma, kariyer olanakları sunma, kültürel çeşitliliği ve cinsiyet eşitliğini sağlama ve yetenek yönetimini içeren "yeteneği cezbetme ve çalışanların tercih ettiği bir şirket olarak tanınma"ya ilişkin içeriğin yoğunluğudur. Bu durum bu kategorideki madde sayısının çokluğu, dolayısıyla kodlama sıklığının artması yanında, şirketlerin sürdürülebilirlik çalışmalarını itibar ve iyi bir işveren konumlarıyla ilişkilendirmeleriyle açıklanabilir. Çalışanların tercih ettiği bir şirket olma hedefi son yıllarda "işveren markası" adıyla anılmaya başlanmıştır. Gözen (2016), işveren markasını itibar, sosyal, gelişim ve ekonomi boyutlarıyla açıklamaktadır. İşveren markasının itibar boyutu, cazip bir çalışma ortamı ile köklü, bilinir ve sosyal bir amacı olan bir kurumda çalışma yoluyla çalışanların kendilerini kurumla özdeşleştirebilmeleri olarak açıklanabilir. Sosyal boyut, çalışanların kendisini kurumda iyi, mutlu hissetmeleri ve iyi ilişkiler kurmaları ile bağıntılıdır. Gelişim boyutu çalışanın gerek sağlanan eğitimlerle, gerekse hazırlanan kariyer planlarıyla kendisini geliştirebileceği bir ortamı ifade ederken; ekonomik boyut en basit anlamıla ücret ve yan haklar temeline dayandırılabilir.

Çalışanlar üzerindeki negatif etkilerin azaltılması kategorisinde en fazla uygulama örneğine sahip alan olarak iş sağlığı ve güvenliği: iş kazaları, yaralanmalar ve ölümcül kazalar riskini azaltma alt kategorisi dikkat çekmektedir. İşs sağlı̆̆ı ve güvenliğiyle ilgili içeriğin, paylaşılan uygulama çeşitliği de düşünüldüğünde bunu Türkiye'de son yıllarda dramatik bir şekilde artan iş kazalarının bir sonucu olarak açılamak mümkündür. Aynı zamanda, bu sonuç Türkiye'de çalışma hayatının kurallarını ve kapsamını belirleyen 4857 sayılı İş Kanunu ve küresel gelişmelere uyum sağlamak amaciyla 2012 y1lında yürürlüğe giren İş Sağlığı ve Güvenliği Kanunu'nun getirdiği yükümlülüklerin de bir sonucu olarak yorumlanmalıdır. Çünkü birçok uygulama gönüllülük esasından ziyade kanun koyucunun yaptırımları neticesinde gerçekleştirilmektedir. 
Diğer yandan, tüm uygulamalar içinde sürdürülebilirliğin çevre boyutuna ilişkin yalnızca üç uygulamaya rastlanmıştır : "Çevresel farkındalık" konulu uzaktan eğitim, yakıt verimliliği ile ilgili alanlarda çalışanlara eğitim verilerek çevre bilincinin artırılması ve çalışanların performans hedefleri arasında sürdürülebilirlik yönetimine ilişkin konuların olması. Sonuncusunun tüm sürdürülebilirlik konularını da kapsayabileceği düşünüldüğünde, sürdürülebilirliğin çevresel boyutuna ilişkin sadece iki örnek uygulama kalmaktadır. Bu sonuç şirketlerin çevresel konulardaki sorumluluklarının yeterince farkında olmadıklarını gösterebileceği gibi, bu konularda yasal yaptırımların eksikliğini de göstermektedir. Nitekim iş sağlı̆̆ 1 ve güvenliği uygulamalarının raporlamada ağırlıklı olması yasal yükümlülüklerin de bir sonucudur. $\mathrm{Bu}$ durumun da vurguladığı gibi, sürdürülebilirlik yaklaşımının içselleştirilmesi ve somutlaşması açısından insan kaynakları yöneticilerine düşen rollerin daha çok araştırılması, incelenmesi ve pratik önerilerin geliştirilmesi gerekmektedir.

\section{Sonuç ve Öneriler}

Her iki araştırmanın sonuçları sürdürülebilirlik bakımından ele alındığında;

1) Şirketlerin sürdürülebilirlik raporlamalarında insan kaynakları yönetimine ilişkin uygulamalar değerlendirildiğinde sosyal sürdürülebilirlik boyutunu destekler bir düzeye ulaşıldığını söylemek çok mümkün değildir. Yeteneği cezbetme ve staj vb programlar aracılığıyla çekirdekten yetiştirmeye verilen yer ve önem şirketlerin sürdürülebilirlik adına yürüttüğü faaliyetlerin önemli bir kısmını rekabet ve karlılık avantajlarını sürdürmeye hizmet ettiği sonucuna götürmektedir. Bunun yanında, yasal zorunluluklar sonucu gerçekleştirilen uygulamaların yoğunluğu da (iş sağlığ1 ve güvenliği, gibi) bu görüşü pekiştirmektedir.

2) Öte yandan, ilk çalışmanın sonuçlarından biri olan özel sektör ve endüstri çalışanlarının, kamu sektörü ve diğer işkollarındaki çalışanlardan daha az çevre yanlısı davranış sergilemeleri ve daha çok statükocu tutum içinde olmaları, bunun yanında şirketlerin çevre dostu uygulamalarının çalışanların çevre yanlısı davranışlarını artırması iş yerlerinde çevresel sürdürülebilirliğe ilişkin yapılması gerekenleri işaret etmektedir. Özellikle, insan kaynakları yönetimleri bakımından Ones ve Dilchert (2014)'in belirttiği çalışan davranışlarını (bkz. Tablo 2) hedefleyecek uygulamaların hayata geçirilmesi hedeflenmelidir.

3) Yasal yaptırımların sürdürülebilirlik uygulamalarını artırdığı düşünülürse, çevresel sürdürülebilirliğin sağlanmasında şirketler bakımından zorunluluk arz edecek yasal düzenlemelerin yapılması önerilebilir. Temiz enerji kullanımı, atık yönetimi, su ve elektrik tasarrufunu teşvik edecek düzenlemeler, sera gazlarının salınımını azaltma gibi uygulamalar yasal düzenlemeler ile zorunlu k1lınmal, tüm bunlara çalışanların çevre yanlısı davranış ve tutumları ile katılmaları hedeflenmelidir. 


\section{Kaynakça/References}

Başar, A. B., \& Başar, M. (2006). Sosyal sorumluluk raporlaması ve Türkiye'deki durumu. Anadolu Üniversitesi Sosyal Bilimler Dergisi, 2(2), 213-230.

Bauer, T. N., \& Aiman-Smith, L. A. (1996). Green career choices: The influence of a firm's ecological stance on perceived company attractiveness. Journal of Business and Psychology, $10,445-458$.

Davis, M. C. \& Challenger, R. (2013). Environmentally sustainable work behaviors. In P.C. Flood \& Y. Freeney (Eds.), Wiley Encyclopedia of Management: Organizational Behavior (3rd ed., Vol. 11).

Doğru, G. (2012) Kurumsal Sürdürülebilirlikte İnsan Kaynakları Yönetiminin Rolü. Dokuz Eylül Üniversitesi. Sosyal Bilimler Enstitüsü Yayınlanmamış Yüksek Lisans Tezi.

Ehnert, I. (2009). Sustainability and human resource management: Reasoning and applications on corporate websites. European J. International Management, 3(4), 419-438.

Ehnert, I. \& Harry, W. (2012). Recent Developments and Future Prospects on Sustainable Human Resource Management: Introduction to the Special Issue. Management Revue, 23(3), 221-238

Fisk, Peter (2010) Sürdürülebilir Büyüme: Insanlar, Gezegen, Kar. Mediacat, İstanbul.

GRI (2017) Sürdürülebilirlik Raporlaması K1lavuzları. https://www. globalreporting.org / resourcelibrary/ Turkish-G4-Part-One.pdf Erişim Tarihi: 10.11.2017

Gözen, E. (2016). "Potansiyel işgörenler açısından işveren markası algısı: Akdeniz üniversitesi turizm öğrencileri örneği”. Journal of Tourism and Gastronomy Studies, 4(1), 70-80.

Jabbour, C. J. C. ve Santos, F. C. A. (2006). The evolution of environmental management within organizations: Toward a common taxonomy. Environmental Quality Management, 16(2), 43-59.

Karaca, Ş. (2013). Tüketicilerin yeşil ürünlere ilişkin tutumlarının incelenmesine yönelik bir araştırma, Ege Akademik Bakış, 13(1) 99-111.

Kılıç, N. ve Vatansever, Ç. (2017) Çalışanların "Yeşil” Tutum ve Davranışları ile Yaşam Değerleri İlişkisi içinde Değerli İnsana Değerli Çalı̧̧malar (Eds.) Turgut, T. Ve Çinko, M. Beta Yayınları. Kuşat, N. (2013). Yeşil sürdürülebilirlik için yeşil ekonomi: Avantaj ve dezavantajları - Türkiye incelemesi. Journal of Yasar University, 29(8), 4896-4916.

Mariappanadar, S. (2003). Sustainable Human Resource strategy: The sustainable and unsustainable dilemmas of retrenchment. International Journal of Social Economics, 30(8), 906-923.

McDonald, S. (2011). Green behaviour: Differences in recycling behaviour between the home and the workplace. In D. Bartlett (Ed.), Going green: The psychology of sustainability in the workplace. Leicester, England: The British Psychological Society.

Ones, D. \& Dilchert, S. (2012). Environmental sustainability at work: A call to action. Industrial and Organizational Psychology, 5, 447-469.

SHRM, BSR, \& Aurosoorya. (2011). Advancing Sustainability: HR's Role. Washington, DC: Society for Human Resource Management.

Paillé, P., Chen, Y., Boiral, O., \& Jin, J. (2014). The impact of human resource management on environmental performance: An employee-level study. Journal of Business Ethics, 121(3), 451-46

PwC (2011) Türk İş Dünyası'nda Sürdürülebilirlik Uygulamaları Değerlendirme Raporu

Ruepert, M. A. Keizer, K ve Steg, L. (2017). The relationship between corporate environmental resposibility, employees' biospheric values and pro-environmental behavior at work. Journal of Environmental Psychology, 54, 65-78. 
Saban, M., Küçüker ve Küçüker (2017). Kurumsal sürdürülebilirlik ile ilgili raporlama çerçeveleri ve sürdürülebilir raporlamada muhasebenin rolü. İşletme Bilimi Dergisi (JOBS), 101-115, DOI: $10.22139 /$ jobs. 291818

Steg, L; Van Den Berg, A. ve De Groot, J.I.M. (2015). Environmental Psychology: An Introduction. Çevre Psikolojisi/ Çeviri: L. K. Cicerali ve E.E. Cicerali. Nobel Yayıncılık. ,

Tokgöz, N., \& Önce, S. (2009). Şirket sürdürülebilirliği: geleneksel yönetim anlayışına alternatif. Afyon Kocatepe Üniversitesi İ̈BF Dergisi, 11(1), 249-275.

Topçu, B., Gazeloğlu, C., \& Yılmaz M. (2015). Akademisyenlerin çevreye karşı olan tutumlarının yapısal eşitlik modellemesi ile incelenmesi, 9. Uluslararası İstatistik Kongresi, Sözel Bildiri, 8 Ekim-01 Kasım 2015 Antalya.

Türşen, E. (2015). Hürriyet İnsan Kaynakları Eki: "Sürdürülebilirlik: Tercihten çok zorunluluk" başlıklı haberi http://www.hurriyet.com.tr/surdurulebilirlik-tercihten-cok-zorunluluk-40002751 Erişim: 30.09.2016

Yıldırım, A. ve Şimşek, H. (2013) sosyal bilimlerde nitel araştırma yöntemleri. Seçkin Kitapevi, Ankara.

Zibarras, L. \& Ballinger, C. (2011). Promoting environmental behaviour in the workplace: A survey of UK organizations. In D. Bartlett (Ed.), Going Green: The Psychology Of Sustainability in the Workplace (pp. 84-90). Leicester, England: The British Psychological Society. 
